\title{
The Fatal Economic Flaws of the Contemporary Campaign Against Vertical Integration
}

\author{
Geoffrey A. Manne, ${ }^{*}$ Kristian Stout ${ }^{* *} \&$ Eric Fruits $^{* * *}$
}

\section{INTRODUCTION}

Among law and economics scholars it has long been a settled matter that vertical integration-whether partial integration by contract or full integration by merger - is typically procompetitive (or, at the very least, competitively ambiguous, and problematic in only very limited, stylized, and theoretical circumstances). ${ }^{1}$ One after another, old case law and outdated economic theories of vertical harm have crumbled, effectively moving what was once a judicial stance of per se illegality to one of near per se legality for such conduct. ${ }^{2}$ Even vertical mergers - the ultimate vertical restraint - have been consistently viewed by scholars and courts as generally procompetitive, supported by substantial empirical literature. ${ }^{3}$

\footnotetext{
* President and Founder of the International Center for Law and Economics, a nonprofit, nonpartisan research center based in Portland, Oregon. He is also a distinguished fellow at Northwestern University Center on Law, Business, and Economics.

** Associate Director of the International Center for Law and Economics.

${ }^{* * *}$ Chief Economist at the International Center for Law and Economics and an adjunct professor of business and economics at Portland State University.

1. See James C. Cooper et al., Vertical Antitrust Policy as a Problem of Inference, 23 INT'L. J. INDUS. ORG. 639, 648 (2005) ("In reviewing this literature, two features immediately stand out: First, there is a paucity of support for the proposition that vertical restraints/vertical integration are likely to harm consumers.... Second, a far greater number of studies found that the use of vertical restraints in the particular context studied improved welfare unambiguously ...."); see also D. Bruce Hoffman, Acting Dir., Bureau of Competition, Fed. Trade Comm'n, Remarks at the Credit Suisse 2018 Washington Perspectives Conference: Vertical Merger Enforcement at the FTC 4 (Jan. 10, 2018), https://www.ftc.gov/system/files/documents/public_statements/1304213/hoffman_vertical_merger_s peech_final.pdf [https://perma.cc/W2NS-C2SK] ("To summarize, overall there is a broad consensus in competition policy and economic theory that the majority of vertical mergers are beneficial because they reduce costs and increase the intensity of interbrand competition. That consensus has support in the empirical research.").

2. See Daniel Sokol, The Transformation on Vertical Restraints: Per Se Illegality, the Rule of Reason, and Per Se Legality, 79 ANTITRUST L.J. 1003, 1008 (2013) (discussing the shift from per se illegality to per se legality in vertical mergers).

3. See infra Section IV.B; David Reiffen \& Michael Vita, Comment: Is There New Thinking on Vertical Mergers?, 63 ANTITRUST L.J. 917, 921 (1994) ("Post-Chicago analysis demonstrates the theoretical possibility of harmful vertical mergers. By itself, however, this is inadequate to justify aggressive antitrust review of these transactions."); see also OECD, Competition Policy Roundtables, Vertical Mergers, 239 (2007), https://www.oecd.org/competition/mergers/39891031.pdf
} 
Increasingly, however, vertical conduct of all sorts, including vertical mergers, has come under increased scrutiny, ${ }^{4}$ most recently driven by broadly "populist" antitrust concerns around big tech platforms. ${ }^{5}$ Much of the new opprobrium for vertical conduct has come from the likes of presidential hopefuls, journalists, political pundits, and activists. ${ }^{6}$ In general, this more "political" opposition to vertical restraints and vertical integration seems to be rooted in a reflexive opposition to "structural favoritism"- - to business models that entail some degree of prioritization or discrimination. ${ }^{7}$ But this ignores the basic economics of the firm and longstanding concepts like joint production, information costs, asset specificity, and entrepreneurial judgment, which can lead to advantages for consumers and for competition from the adoption of superficial market restraints, including the vertical integration of some - but not other-input and output providers. ${ }^{8}$

More concerning, however, a fair amount of the resurgence in opposition to vertical restraints and mergers has come from academic economic quarters. ${ }^{9}$ Surprisingly, this criticism of vertical conduct also

[https://perma.cc/W6QX-PJ5N] (“[V]ertical mergers merit a stronger presumption of being efficient than do horizontal mergers, and should be allowed to proceed except in those few cases where convincing, fact-based evidence relating to the specific circumstances of the vertical merger indicates likely competitive harm.").

4. See, e.g., Steven C. Salop, Invigorating Vertical Merger Enforcement, 127 YALE L.J. 1962, 1982 (2018) [hereinafter Salop, Invigorating] (noting that "action . . . to modernize vertical merger enforcement policy" requires "recognizing the substantial potential harms from vertical and complementary product mergers").

5. See, e.g., Sen. Elizabeth Warren, Here's How We Can Break Up Big Tech, Medium (Mar. 8, 2019), https://medium.com/@teamwarren/heres-how-we-can-break-up-big-tech-9ad9e0da324c [https://perma.cc/8TG3-ZLBS] ("That's why my administration will make big, structural changes to the tech sector to promote more competition-including breaking up Amazon, Facebook, and Google."); see also Emily Craig, Vestager Considers Shifting Burden of Proof for Big Tech, GLOBAL COMP. Rev. (Oct. 31, 2019), https://www.lexology.com/library/detail.aspx?g=b7159a3d-ae2e-4e87 -ba37-e59f9200c2c4 [https://perma.cc/6E2H-MAJS] ("EU competition commissioner Margrethe Vestager is considering shifting the standard of proof onto large technology companies to prove the effects of their conduct are not anticompetitive.").

6. Id.

7. See Warren, supra note 5 ("But where the value of the company came from its network, reformers recognized that ownership of a network and participating on the network caused a conflict of interest. Instead of nationalizing these industries - as other countries did-Americans in the Progressive Era decided to ensure that these networks would not abuse their power by charging higher prices... and favoring some over others. We required a structural separation between the network and other businesses, and also demanded that the network offer fair and non-discriminatory service.").

8. See infra Section II.B.

9. See, e.g., Salop, Invigorating, supra note 4, at 1982-84; see also Carl Shapiro, Protecting Competition in the American Economy: Merger Control, Tech Titans, Labor Markets, 33 J. ECON. PERSP. 69, 69 (2019) ("[E]vidence is mounting that the largest US firms account for a growing share of economic activity, and that profits and price/cost margins at these firms have grown sharply in recent decades. Meanwhile, the economic might of the largest tech firms seems to grow without bound. Have our antitrust laws and institutions failed us?"); Jonathan B. Baker et al., Five Principles 
misunderstands or ignores fundamental economic concepts.

One prominent line of criticism of vertical mergers, for example, notes an overlap of vertical mergers with vertical contracts, and proposes to prohibit or significantly deter vertical integration by merger because it inherently leads to competitive problems that either do not exist or can more easily be corrected in vertical contracts. ${ }^{10}$ But the choice between merger and contract for firms is not so simple, especially in highly dynamic industries in which effective competition often demands both process and product innovation. In particular, the management of intangible information assets - often the crucial inputs in dynamic, hightech firms - may not be as readily (or at all) accomplished by contract as by internal coordination. ${ }^{11}$ In the face of extreme informational uncertainties and the need for the inherently uncertain exercise of entrepreneurial judgment and dynamic capabilities (which reside in a firm's individual decisionmakers, corporate culture, and collective ability to implement novel business processes), ${ }^{12}$ contracts cannot always replicate the competitive advantages of integration through merger.

This narrow view of vertical integration thus ignores and threatens to undermine dynamic competition and innovation. Indeed, if we take the organization theory and business strategy literature on the organization of firms in dynamic industries seriously, ${ }^{13}$ the status quo might even be over-

for Vertical Merger Enforcement Policy, 33 ANTITRUST 12, 17 (“'[M]odern economic analysis does not support a relaxed approach to vertical merger review and enforcement.").

10. See infra Section II.A.; Fed. Trade Comm'n, Hearings on Competition and Consumer Protection in the 21st Century: FTC Hearing \#5: Vertical Merger Analysis and the Role of the Consumer Welfare Standard in U.S. Antitrust Law, Presentation Slides, at 24 (Nov. 1, 2018), https:// www.ftc.gov/system/files/documents/public_events/1415284/ftc_hearings_5_georgetown_slides.pdf [hereinafter FTC Hearing \#5 Presentation Slides] ("Efficiencies often can be achieved by vertical contracts, without the potential anticompetitive harms from merger."); U.S. DEP'T OF JUSTICE \& FED. TRADE COMM'N, DRAFT JOINT Vertical MERger GUIDELINES $\S 6$ (Jan. 10, 2020), https://www.justice.gov/opa/press-release/file/1233741/download [https://perma.cc/YU3S-9Q9Y] [hereinafter DRAFt JoINT VerTiCAl MERGER Guidelines] ("The effects of the elimination of double marginalization may be lower if, prior to the merger, the merging parties already engaged in contracting that aligned their incentives, for example by using a two-part tariff with a fixed fee and low unit prices that incorporate no, or a small, margin.").

11. See infra Part V.

12. See D. Daniel Sokol, Vertical Mergers and Entrepreneurial Exit, 70 FLA. L. REV. 1357, 1371-73 (2018).

13. See Ashish Arora \& Alfonso Gambardella, Complementarity and External Linkages: The Strategies of the Large Firms in Biotechnology, 38 J. INDUS. ECON. 361, 374 (1990) (noting that in R\&D heavy industries "[t]he locus of innovation should be thought of as a 'network' of interorganizational relations" as opposed to focusing solely on single-firm boundaries); see also Michael G. Jacobides \& Stephan Billinger, Designing the Boundaries of the Firm: From "Make, Buy, or Ally" to the Dynamic Benefits of Vertical Architecture, 17 ORG. SCI. 249, 250 (2006) ("Thus, vertical architectures shape the pattern of transactional choices, and we find that they have important systemic properties that go well beyond transactional alignment."); Gautam Ahuja \& Riitta Katila, 
enforcing, and leading to the deterrence of innovative, procompetitive mergers. It is insufficient merely to advert to potential price effects or innovation effects on foreclosed competitors or input providers, and there truncate the analysis. A proper evaluation of the competitive effects of vertical conduct requires an assessment of industrywide increases in innovation and of quality improvements that may accompany superficial price increases or localized constraints on innovation. ${ }^{14}$ Without this it is impossible to conclude that such conduct is anticompetitive.

This paper proceeds as follows. First, we examine the academic calls for stronger presumptions against vertical mergers based on, among other things, the alleged substitutability of contract for merger as a means of vertical integration, and the alleged equivalence of harms that arise from vertical and horizontal mergers. We analyze these claims on their own terms before proceeding in the next part to survey the economic literature that undermines the foundation of these arguments. We then proceed to analyze the critical differences between horizontal and vertical mergers that makes conflation of these two distinct methods of business combination impossible to truly treat as analytically equivalent. Next, we discuss the mistake of substituting static analysis for a more thorough dynamic analysis, particularly in industries marked by fluid product cycles and flexible business models. Finally, we conclude.

\section{VERTICAL MERGERS AND THEIR DisCONTENTS}

Vertical mergers entail the combination into a single firm of companies operating at different levels of the same supply or production chain. ${ }^{15}$ Examples of such vertical integrations are manifold throughout the economy. Indeed, it is even arguably the case that virtually every firm could be considered vertically integrated to one degree or another insofar as it provides some of its own operation's inputs (e.g., a restaurant also

Technological Acquisitions and the Innovation Performance of Acquiring Firms: A Longitudinal Study, 22 StRat. MGMT. J. 197, 197 (2001) (examining "the impact of acquisitions on the subsequent innovation performance of acquiring firms"); Claudio Wolter \& Francisco M. Veloso, The Effects of Innovation on Vertical Structure: Perspectives on Transaction Costs and Competences, 33 ACAD. MGMT. ReV. 586, 601 (2008) (noting that it is "relevant for [firms] to learn how to organize their firms' vertical structure so as to become innovators," and in particular how "[u]nderstanding what kind of products, activities, and services to outsource prior to a determined innovative regime coming into place ... can lead to long-term competitive advantages and, consequently, survival").

14. See infra Part V.

15. See, e.g., Draft Joint Vertical Merger Guidelines, supra note 10, $\S 1$ n.2 ("Vertical mergers combine firms or assets that operate at different stages of the same supply chain.... In describing a vertical relationship, the stage closer to final consumers (such as a distributor, retailer, or finished goods manufacturer) is termed 'downstream,' and the stage farther from final consumers (such as a supplier, wholesaler, or input manufacturer) is termed 'upstream."'). 
performs its own accounting in-house) or operates its own logistics systems (e.g., a manufacturer also owns and manages its own trucks and makes its own deliveries). In some industries, many firms are vertically integrated along all levels of production: many petroleum firms are vertically integrated from exploration and production, to refining and retail fuel stations $;{ }^{16}$ many restaurants are vertically integrated "from farm to table." 17 At the same time, many retail fuel stations and restaurants operate independently, purchasing their inputs from suppliers, contracting out their logistics, and competing effectively against vertically integrated firms in the same market. ${ }^{18}$

The ubiquity of such arrangements and the multifarious ways in which such integrations can improve firms' operations and increase efficiency have generally led courts and enforcers to view vertical mergers with far less skepticism than their horizontal counterparts. ${ }^{19}$ Nonetheless, in some quarters there is dissatisfaction with the state of vertical merger policy in the United States.

In 2018, the Federal Trade Commission (FTC) conducted hearings to look at the current state of competition law. ${ }^{20}$ One of the themes that emerged was a dissatisfaction with both the current 1984 vertical merger guidelines as well as with the state of vertical merger enforcement.

In his introductory remarks at the hearing on vertical mergers, FTC Commissioner Noah Phillips asserted that the current vertical merger

16. See, e.g., David J. Teece, Vertical Integration and Vertical Divestiture in the U.S. Petroleum Industry 75-81 (Stanford Graduate Sch. of Bus., Working Paper No. 300, 1976), https://www.gsb .stanford.edu/faculty-research/working-papers/vertical-integration-vertical-divestiture-us-petroleumindustry [https://perma.cc/ZHH2-PTQC] (discussing the comprehensive vertical integration of the U.S. oil industry and its impact on competition).

17. See, e.g., Cindy Elliot, Supply Chain Integration Fuels New Farm-to-Table Movement, ESRI (Nov. 14, 2017), https://www.esri.com/about/newsroom/publications/wherenext/supply-chain -integration-fuels-new-farm-to-table-movement/ [https://perma.cc/LEV9-5VQB] (discussing the vertical integration inherent in "farm-to-table" restaurants).

18. See, e.g., Selling America's Fuel, NACS (Apr. 12, 2019), https://www.convenience.org /Topics/Fuels/Who-Sells-Americas-Fuel [https://perma.cc/G2B6-DXZW] (noting that approximately $80 \%$ of the fuel sold in the US is vended at convenience stores that are unlikely to be integrated with oil companies).

19. See Christine S. Wilson, Comm'r, Fed. Trade Comm'n, Keynote Address at the GCR Live 8th Annual Antitrust Law Leaders Forum: Vertical Merger Policy: What Do We Know and Where Do We Go?, at 4 (Feb. 1, 2019), https://www.ftc.gov/system/files/documents/public statements/1455670 /wilson_-_vertical_merger_speech_at_gcr_2-1-19.pdf [https://perma.cc/9225-LY44] (“[W]e know that competitive harm is less likely to occur in a vertical merger than in a horizontal one.").

20. See Joe Simons, Chairman, Fed. Trade Comm'n, Prepared Remarks of Chairman Joe Simons: Hearings on Competition and Consumer Protection in the 21st Century (Sept. 13, 2018), https:// www.ftc.gov/system/files/documents/public_statements/1409925/opening_remarks_of_joe_simons _hearings1georgetown_sept2018_0.pdf [https://perma.cc/44TF-V9ZJ] (introducing the FTC hearings). 
guidelines "are outdated and do not reflect current agency practice," 21 and Paul Yde commented that "nobody pays any attention to the " 84 guidelines anymore." 22 Critics of the 1984 guidelines argued that they "[d]o not reflect current economic learning" and do not reflect actual agency practice. ${ }^{23}$ Professor Carl Shapiro, for example, argues that the current guidelines do not address unilateral effects, and "there has been a lot of learning and a complete shift in agency enforcement related to unilateral [effects]" since the guidelines were published. ${ }^{24}$

Spurred on by such concerns, the Department of Justice (DOJ) and the FTC have announced new draft Joint Vertical Merger Guidelines. ${ }^{25}$ Although the draft guidelines do not adopt most of the critics' suggestions, they do move away from the existing guidelines to some degree. For example, the draft guidelines remove the 1984 guidelines' prefatory language, suggesting that vertical mergers may be less concerning than horizontal mergers. ${ }^{26}$ They also specifically recognize Post-Chicago theories of potential vertical harm arising from foreclosure, raising rivals' costs, and information sharing. ${ }^{27}$

Although it is doubtlessly correct that the 1984 guidelines do not reflect the latest economic knowledge, it is by no means clear that this has been a problem — or that a new set of guidelines would not create even greater problems. ${ }^{28}$ Indeed, as the former DOJ Antitrust Division Acting Assistant Attorney General, Sharis Pozen, remarked at the FTC's hearing, the possible disconnect between the current guidelines and agency

21. Fed. Trade Comm'n, Hearings on Competition and Consumer Protection in the 21st Century: FTC Hearing \#5: Vertical Merger Analysis and the Role of the Consumer Welfare Standard in U.S. Antitrust Law, Transcript, at 7 (Nov. 1, 2018), https://www.ftc.gov/system/files/documents/public _events/1415284/ftc_hearings_session_5_transcript_11-1-18_0.pdf [https://perma.cc/H9WB-T7BS] [hereinafter FTC Hearing \#5 Transcript].

22. Id. at 109 (statement of Paul Yde, Partner, Freshfields Bruckhaus Deringer).

23. FTC Hearing \#5 Presentation Slides, supra note 10, at 9.

24. FTC Hearing \#5 Transcript, supra note 21, at 57 (statement of Carl Shapiro, Professor, University of California-Berkeley).

25. Draft Joint Vertical Merger Guidelines, supra note 15.

26. Compare id. §1(a)-(c) ("Vertical mergers, however, also raise distinct considerations") with DeP’T OF Justice, NON-Horizontal MERGER Guidelines § 1 (1984), https://www.justice.gov /atr/page/file/1175141/download [https://perma.cc/65DA-CEQ2] [hereinafter NON-HORIZONTAL MERGER GUIDELINES] (“Although nonhorizontal mergers are less likely than horizontal mergers to create competitive problems, they are not invariably innocuous.").

27. Draft Joint Vertical Merger Guidelines, supra note $10, \S 5(\mathrm{a})-(\mathrm{b})$. The draft guidelines do not, however, take up the call to adopt an "evasion of price regulation" theory. See Steven C. Salop \& Daniel P. Culley, Revising the U.S. Vertical Merger Guidelines: Policy Issues and an Interim Guide for Practitioners, 4 J. ANTITRUST ENFORCEMENT 1, 39 (2015); Michael H. Riordan \& Steven C. Salop, Evaluating Vertical Mergers: A Post-Chicago Approach, 63 ANTITRUST L.J. 513, 561 (1995).

28. See FTC Hearing \#5 Transcript, supra note 21, at 148 (statement of Sharis Pozen, Partner, Clifford Chance). 
learning and practice is of little concern: "I do not feel uncertainty because I do not have vertical guidelines. I have uncertainty because I do not know what the state of play is right now, particularly at the Department of Justice on these issues. $" 29$

\section{A. The Foundational Justifications for Enhanced Vertical Merger Enforcement}

Nonetheless, several scholars-most notably, economist Steven Salop - have been energetic in their criticism of the current nonhorizontal merger guidelines as well as the general state of vertical merger enforcement. ${ }^{30}$ Importantly, not only has Salop asserted that the guidelines fail to reflect actual agency enforcement, he has also argued that both the guidelines and the vertical merger enforcement practices at the FTC and DOJ fail to reflect the current state of economic learning concerning vertical conduct. ${ }^{31}$ Moreover, his current recommendations are more vigorous than the recommendations for reform he has offered in the past. ${ }^{32}$ In 1995, for example, he argued for more enforcement, but "[b]ecause of the potential for efficiency benefits, it is appropriate in many cases to adopt a decision structure that requires the complaining party to demonstrate a significant likelihood of injury to consumers; harm to competitors is insufficient." 33 Today, by contrast, Professor Salop argues for a "reasonable probability" of consumer harm evidentiary standard, ${ }^{34}$ recommends anti-merger presumptions based on competitor harms, ${ }^{35}$ and

29. Id. at 148; see also James Langenfeld, The Need to Revise the U.S. Non-Horizontal Merger Guidelines, in On-Topic: What is Trump Antitrust?, CONCURRENCE, Nov. 2016, at 51, 51 ("Unfortunately, the U.S. antitrust agencies have not updated their Non-Horizontal Merger Guidelines for 32 years, even though . . . the antitrust agencies have revised the Horizontal Merger Guidelines 6 times over the last 48 years [and] the competition agencies ... have challenged a number of major mergers between firms that do not directly compete with one another .... It has been argued that [the Non-Horizontal Merger Guidelines] should not be updated because there is not a sufficient consensus about how to analyze them, [and] because a public statement about merger enforcement would encourage more active enforcement than merited ...." (internal citations omitted)).

30. See, e.g., Salop \& Culley, supra note 27, at 3-4.

31. Id. ("Those Guidelines are now woefully out of date. They do not reflect current economic thinking about vertical mergers. Nor do they reflect current agency practice. Nor do they reflect the analytic approach taken in the 2010 Horizontal Merger Guidelines." (footnotes omitted)); see also Salop, Invigorating, supra note 4, at 1982-84 ("The 1984 Non-Horizontal Guidelines are out-ofdate.").

32. Compare Riordan \& Salop, supra note 27, at 564, with FTC Hearing \#5 Presentation Slides, supra note 10, at 24.

33. Riordan \& Salop, supra note 27, at 564.

34. FTC Hearing \#5 Presentation Slides, supra note 10, at 34.

35. Id. at 32 ("When a vertical merger enables the merged firm to raise its rivals' costs, competition is lessened substantially."). 
adopts a strong presumption against efficiencies. ${ }^{36}$

Foundational to his criticisms, Salop argues (and believes current enforcement practices fail to recognize) that vertical mergers can result in harms that are analytically equivalent to harms that arise from impermissible horizontal mergers:

There are similar inherent market power concerns that arise from vertical mergers in oligopoly markets just as they arise from horizontal mergers. Consider the common vertical merger scenario where the upstream merging firm was competing in the pre-merger world to sell inputs to the unintegrated downstream firms that compete with its future downstream merger partner. In this scenario, that upstream firm was effectively a pre-merger "partner" of these unintegrated downstream competitors. After merging, the upstream firm would obtain foreclosure incentives to raise their costs and prices. This is analogous to the price-raising effects of a hypothetical horizontal merger between the downstream merging firm and its competitors. Indeed, it is analytically similar if not equivalent to a standard unilateral effects model. Thus, there is an inherent horizontal effect even in this common vertical merger scenario. ${ }^{37}$

According to this criticism, the traditional explanations for the laxer treatment ${ }^{38}$ of vertical (as opposed to horizontal) mergers are faulty:

[T] he Chicago School's skepticism toward ... the competitive risks of vertical mergers ... rests on three main claims: (1) foreclosure is illusory because vertical mergers simply realign vertical relationships rather than reduce supply; (2) anticompetitive foreclosure generally would not be profitable; and (3) vertical mergers are invariably efficient, particularly because of elimination of double marginalization. However, modern economic analysis demonstrates that these theories do not provide a valid basis for such limited enforcement. Instead, modern analysis shows that competitive harm can in fact result from vertical mergers when markets are imperfectly competitive .... [Thus,] the first two claims never had a strong economic basis and have been steadily and powerfully debunked by economists, while the third cannot carry the burden to support

36. Id. at 24 ("Merging parties must provide rigorous explanation, identifying specific pre-merger impediments that are not themselves anticompetitive. They must explain why [these] impediments [are] solved by the merger.").

37. Steven C. Salop, Modernizing the Vertical Merger Guidelines, CPI ANTITRUST CHRON., July 24, 2019, https://www.competitionpolicyinternational.com/modernizing-the-vertical-mergerguidelines/ (emphasis added).

38. According to Professor Salop:

Since that time, vertical merger challenges have been infrequent. From 1994 to 2016, U.S. agencies have challenged only fifty-two mergers that involved vertical integration, and some of these also involved horizontal overlaps. In merger enforcement involving mergers with both vertical and horizontal components, the FTC and the Department of Justice (DOJ) typically focused only on the horizontal overlaps.

Salop, Invigorating, supra note 4, at 1964-65. 
nonenforcement. ${ }^{39}$

Further, a fundamental basis for Professor Salop's claims regarding heightened scrutiny of vertical mergers is his contention that virtually anything - any efficiencies - that can be realized by merger can typically be created by contract. ${ }^{40}$ He relies on Coase to support his argument: "[Placing] the burden of production for showing that efficiencies are merger-specific on the merging parties, not the plaintiff[,] ... makes economic sense for vertical mergers. As emphasized by Ronald Coase, vertical contracts can be a good substitute for vertical integration, absent significant transactions costs." 41

Salop thus argues that the existence of a contract solution to firm problems can generate the same sorts of efficiencies as when firms opt to merge (and because, as noted above, vertical mergers create the same inherent risks as horizontal mergers); therefore, it follows that enforcers and courts should generally adopt a policy against vertical mergers relative to the status quo:

Efficiencies often can be achieved by vertical contracts, without the potential anticompetitive harms from merger. In that vertical restraints are characterized as "just" vertical integration "by contract," then claimed efficiencies in problematical mergers might be achieved with non-merger contracts that do not raise the same anticompetitive concerns. ${ }^{42}$

The upshot of these criticisms is, at bottom, a preference for more enforcement against vertical integration over the status quo. ${ }^{43}$ If the intellectual justification for the current enforcement regime is systematically biased against recognizing the true harms from vertical mergers, it follows that it is highly likely that enforcers will miss a significant number of vertical mergers that result in harm, and, therefore, that the regime needs to be adjusted to generate a relatively larger amount of enforcement activity.

Salop is not alone in drawing such a conclusion; Carl Shapiro has

39. Id. at 1966

40. See Steven C. Salop, The AT\&T/Time Warner Merger: How Judge Leon Garbled Professor Nash, 6 J. ANTITRUST ENFORCEMENT 459, 468 (2018) [hereinafter Salop, AT\&T].

41. Id.

42. FTC Hearing \#5 Presentation Slides, supra note 10, at 24.

43. See, e.g., Salop, Invigorating, supra note 4, at 1969 ("But the market conditions under which the theory [supporting pro-vertical merger presumptions] applies are far too narrow to create a procompetitive enforcement or legal presumption.”). 
made a similar point:

[I]t is important to recognize that, while we must assume that a vertical merger will lead to the elimination of double marginalization ["EDM"], this does not imply that EDM is merger-specific. That is a factual question that must be assessed on a case-by-case basis. For example, if other firms in the industry have managed to eliminate double marginalization through contract, perhaps by using two-part tariffs or other non-linear pricing schemes, the merging firms might well be able to do likewise. In that case, EDM is not merger specific and should not be credited as an efficiency in the merger analysis. In the AT\&T/Time Warner case, my analysis credited EDM as merger-specific. ${ }^{44}$

\section{B. The Foundational Problems with the Foundational Justifications}

It is true that, where contracts are observed, they are likely more efficient than mergers. But, by the same token, it is also true that where mergers are observed, they are likely more efficient than contracts. Indeed, as we discuss in the next part, the entire reason for integration is efficiency relative to what could be done by contract - this is the essence of the so-called "make-or-buy" decision. ${ }^{45}$ A firm that decides to buy its own warehouse has determined that doing so is more efficient than renting warehouse space. Some of these efficiencies can be measured and quantified (e.g., carrying costs of ownership vs. the cost of rent), but many efficiencies cannot be easily measured or quantified (e.g., layout of the facility or site security). Under Professor Salop's reasoning, the benefits of owning a warehouse can be achieved often by renting warehouse space. But the fact that many firms using warehouses own some space and rent some space indicates that the make-or-buy decision is often unique to each firm's idiosyncratic situation.

And there is no reason to presume in any given situation that the outcome from contracting would be the same as from merging. The two are, quite simply, different bargaining environments, each with a different risk allocation, different accounting treatment, different tax consequences, etc. Even if the parties accomplished "identical" outcomes, they would not, in fact, be identical.

Meanwhile, what if the reason for failure to contract, or the reason to prefer merger, has nothing to do with efficiency? What if there were no

44. Carl Shapiro, Testing Vertical Mergers for Input Foreclosure, ORG. FOR ECON. COOPERATION \& DEV. 6 (June 7, 2019), https://one.oecd.org/document/DAF/COMP/WD(2019)75 /en/pdf [https://perma.cc/GNC8-NZ65].

45. Id. 
anticompetitive aim, but instead there were a tax advantage $?^{46}$ What if one of the parties just wanted a larger firm in order to satisfy the CEO's ego? That these are not cognizable efficiencies under antitrust law is clear. But the adoption of a presumption of equivalence between contract and merger would entail their incorporation into antitrust law in much the same way, except in the negative. In other words, if the assumption is that contract and merger are equally efficient unless proven otherwise, but the law adopts a presumption against mergers - which can be rebutted only with highly burdensome evidence of net efficiency gain-this effectively deputizes antitrust law to enforce a preconceived notion of merger appropriateness that does not turn on efficiencies.

In truth, and as we discuss at length below, both of the critics' foundational claims - that vertical and horizontal mergers have equivalent effects and that vertical contracting can accomplish the same ends as vertical mergers (and at lower risk) - are faulty. First, while it may sometimes be true that the mechanism of harm is the same, because a vertical merger removes only a potential competitor, while a horizontal merger removes an actual competitor, the risk of harm is not the same. By the same token, the mechanisms are not always the same, and the imposition of harm resulting from a vertical merger often requires an additional step, which may or may not come about. This further attenuates the risk of harm.

More fundamentally, however, while there are surely some situations in which contractual restraints might be able to achieve similar organizational and efficiency gains as a merger, the practical realities of achieving not just greater efficiency, but a whole host of non-efficiencyrelated, yet nonetheless valid, goals are rarely equivalent between the two. For example, it may be that the parties don't know what they don't know to such an extent that a contract would be too costly because it was too incomplete. Incomplete contracts and ambiguous control and ownership rights are not ongoing issues with a merger like they are for contractual arrangements. There is no basis for assuming that the structure of a merger and a contract would be identical. In the same way, there is no basis for assuming that the knowledge transfer that would result from a merger would be the same as that which would result from a contractand in ways that the parties could specify or reliably calculate in advance. Knowing that the prospect for knowledge "synergies" would be higher

46. See, e.g., Frederick R. WARren-Boulton, Vertical Control of Markets: Business AND LABOR PRACTICES 35 (1978) ("Both vertical integration and tying arrangements have been used to avoid or reduce certain categories of taxation. The clearest example is a turnover tax, which is levied on all sales rather than on value-added or just final sales."). 
with a merger than a contract might be sufficient to induce the merger outcome. But asked to provide evidence that the parties could not engage in the same conduct via contract, the parties would be unable to do so. The consequence, then, would be the loss of potential gains from closer integration.

At the same time, the cavalier assumption that parties would be ablelegally-to enter into an analogous contract in lieu of a merger is problematic, given that it would likely be precisely the form of contract (foreclosing downstream or upstream access) that is alleged to create problems with the merger in the first place. ${ }^{47}$ Indeed, legal risk is one of the reasons why a merger might be preferable to a contract, and because the relevant markets here are oligopoly markets, the possibility of impermissible vertical restraints between large firms with significant market share is quite real.

More importantly, the assumptions underlying the contention that contracts and mergers are functionally equivalent legal devices simply ignores the real world. Consider that one reason some takeovers are hostile is because incumbent managers do not want to merge, and often believe that they are running a company as well as it can be run-that a change of corporate control would not improve efficiency. The same presumptions may also underlie refusals to contract and, even more likely, may explain why, to the other firm, a contract would be ineffective.

But, while there is no way to contract without bilateral agreement, there is a corporate control mechanism to force a transaction. ${ }^{48}$ In this institutional environment, a merger may be easier to realize than a contract. In this case, again, the assumption that contract should be the relevant baseline and the preferred mechanism for coordination is misplaced-even if other firms in the industry are successfully accomplishing the same thing via contract.

Finally, the fixation on the equivalency of the form of vertical integration (i.e., merger versus contract) is likely to lead enforcers to focus on static price and cost effects, and miss the dynamic organizational and informational effects that lead to unexpected, increased innovation across and within firms. As Harold Demsetz put it, "[i]t is a mistake to confuse the firm of economic theory with its real-world namesake. The chief

47. See FTC Hearing \#5 Transcript, supra note 21, at 73 (statement of Francine Lafontaine, Professor, Michigan-Ross) ("I want to reemphasize that there are also rules against vertical restraints in antitrust laws, and so to say that the firms could achieve the mergers outcome by using vertical restraints is kind of putting them in a circular motion where we are telling them you cannot merge because you could do it by contract, and then we say, but these contract terms are not acceptable.").

48. Henry G. Manne, Mergers and the Market for Corporate Control, 73 J. POL. ECON. 110, 117 18 (1965). 
mission of neoclassical economics is to understand how the price system coordinates the use of resources, not to understand the inner workings of real firms." ${ }^{49}$ In the hands of Oliver Williamson (and the enterprise of Transaction Cost Economics, for which he was awarded the Nobel Prize), this means that understanding firms in the real world (notably for purposes of antitrust policy and enforcement) entails taking an organization theory approach, in contrast to the "orthodox" economic perspective:

The lens of contract approach to the study of economic organization is partly complementary but also partly rival to the orthodox [neoclassical economic] lens of choice. Specifically, whereas the latter focuses on simple market exchange, the lens of contract is predominantly concerned with the complex contracts. Among the major differences is that nonstandard and unfamiliar contractual practices and organizational structures that orthodoxy interprets as manifestations of monopoly are often perceived to serve economizing purposes under the lens of contract. A major reason for these and other differences is that orthodoxy is dismissive of organization theory whereas organization theory provides conceptual foundations for the lens of contract. ${ }^{50}$

Properly understood, and as we discuss in subsequent parts, the choice of whether to contract or merge derives from a host of complicated factors, made all the more complicated in the case of some R\&D-intensive, hightech firms because they deliver by the fact that there is an incredible degree of flexibility in the products and business models they deliver. ${ }^{51}$ Simplistic static analyses are too rigid for the purpose of analyzing firms that, on the surface, appear to be in separate markets, but that actually generate entire ecosystems locked in head-to-head competition with each other. This competition often manifests not in price, but in both technological and business model (organizational) innovation. ${ }^{52}$

Thus, there can be no legally relevant inference drawn against a company when it chooses one method of vertical integration over another in the general case, and even less so in the case of firms in highly dynamic industries. Despite assertions to the contrary, the economics literature continues to support the idea that vertical mergers are generally procompetitive and there is no need to disrupt the current approach to enforcement in the context of vertical mergers.

49. Harold Demsetz, The Structure of Ownership and the Theory of the Firm, 26 J.L. ECON. 375, 377 (1983).

50. Oliver E. Williamson, Examining Economic Organization Through the Lens of Contract, 12 INDUS. \& CORP. CHANGE 917, 917 (2003) (emphasis added).

51. See Thomas M. Jorde \& David J. Teece, Rule of Reason Analysis of Horizontal Arrangements: Agreements Designed to Advance Innovation and Commercialize Technology, 61 ANTITRUST L.J. 579, 591-92 (1993).

52. See generally infra Part V. 


\section{THE FundAMENTAL ECONOMICS OF VERTICAL MERGERS}

Although it is inarguably true that economic learning regarding vertical integration has significantly progressed since the adoption of the 1984 guidelines, there is no reason to believe that the nature of vertical integration needs to be completely reconceptualized. As we discuss below, the established presumption in favor of permitting vertical integration through merger remains sound policy.

Vertical integration can clearly generate efficiencies. ${ }^{53}$ After all, the elimination of double marginalization (EDM) is, in a sense, just a proxy for all of the benefits that arise from a more efficient supply chain. ${ }^{54}$ In a statement during the 2018 FTC hearings, FTC Commissioner Christine Wilson echoed this point with respect to vertical mergers:

[I]n contrast to horizontal guidelines, the economics in vertical mergers indicate efficiencies are much more likely. Professor Shapiro went so far as to call them "inherently" likely at our hearing. Given this dynamic, it may be appropriate to presume that certain vertical efficiencies are verifiable and substantial in the absence of strong evidence to the contrary, even if we would not do so in a horizontal merger case. ${ }^{55}$

By contrast, the core of the arguments presented above against vertical mergers - as exemplified in Professor Salop's work - is rooted in a belief that mergers and contracts are usually equally capable of realizing the positive results from vertical integration, and therefore, the choice to merge - absent affirmative demonstration that contracting is not viablemust instead be presumed to be based on anticompetitive ends. ${ }^{56}$ This misconception does not do justice to the rich literature that studies the make-or-buy decisions that firms face.

\section{A. The Underlying "Make-or-Buy” Decision}

The extent of vertical integration is often characterized as the "makeor-buy decision." ${ }^{, 57}$ As Ronald Coase identified in 1937, transaction costs determine the boundary between what is produced within the firm and

53. Wilson, supra note 19, at 4 ("[W]e know that integrating operations at different levels of production often yields clear economic benefits.").

54. $I d$.

55. Id. at 9 .

56. FTC Hearing \#5 Presentation Slides, supra note 10, at 24-26.

57. See Oliver E. Williamson, Nobel Prize Lecture, Transaction Cost Economics: The Natural Progression 471 (Dec. 8, 2009), https://www.nobelprize.org/uploads/2018/06/williamson_lecture.pdf [https://perma.cc/NA3J-Z8W3]. 
what is purchased from the market. ${ }^{58}$ When the cost of contracting across firms becomes too high, it may make sense to merge into a firm (or to restructure an existing one) in order to organize internally. ${ }^{59}$ "[T]he firm is the inclusive set of transactions for which the decision is to make rather than buy." $" 60$

Of course, "make-or-buy" is shorthand for a much broader concept. In addition to the decision whether to produce an input in-house or buy the input in the market, firms face a broad spectrum of analogous choices. Firms must choose whether to hire labor as employees or independent contractors. In real estate, they choose whether to own or rent property. For intellectual property, they choose whether to invent or license. For retail sales, firms are faced with a wide-range of options: company stores, franchise, license, wholesale sales, direct-to-retail, or direct-to-consumer. It is because of this range of decisions that Coase describes vertical integration as a spectrum along which the firm chooses the extent to which the "complicated market structure with exchange transactions is substituted [by] the entrepreneur co-ordinator, who directs production." ${ }^{\prime \prime}$

In the first pages of the Wealth of Nations, Adam Smith describes the "trifling manufacture" of pins, an example that highlights the diversity and complexity of operations over which the decision to vertically integrate must be made. ${ }^{62}$

[A] workman not educated to this business ... could scarce, perhaps, with his utmost industry, make one pin in a day, and certainly could not make twenty. But in the way in which this business is now carried on, not only the whole work is a peculiar trade, but it is divided into a number of branches, of which the greater part are likewise peculiar trades. One man draws out the wire, another straights it, a third cuts it, a fourth points it, a fifth grinds it at the top for receiving, the head; to make the head requires two or three distinct operations; to put it on is a peculiar business, to whiten the pins is another; it is even a trade by itself to put them into the paper; and the important business of making a pin is, in this manner, divided into about eighteen distinct operations, which, in some manufactories, are all performed by distinct hands, though in others the same man will sometimes perform two or three of them. I have seen a small manufactory of this kind, where ten men only were employed .... Those ten persons, therefore, could make among them

58. Ronald Coase, The Nature of the Firm, 4 ECONOMICA 386, 394-95 (1937).

59. Id. at 390 ("The main reason why it is profitable to establish a firm would seem to be that there is a cost of using the price mechanism.").

60. See Williamson, supra note 57 , at 471 .

61. Coase, supra note 58, at 388.

62. AdAM SMith, AN INQUIRY INTO THE NATURE AND CAUSES OF THE WEALTH OF NATIONS 3 (Robert Maynard Hutchins ed., William Benton 1952) (1776). 
upwards of forty-eight thousand pins in a day. ${ }^{63}$

Smith's review of the pin factory is often used to describe how the division of labor can increase productivity. However, without directly saying so, Smith is describing vertical integration. First, he contrasts a vertically integrated sole proprietor ("a workman not educated to this business") with a 10 -employee factory. ${ }^{64} \mathrm{He}$ notes that some factories divide labor into one-person/one-task and others have some employees doing several tasks. ${ }^{65}$ Thus, even among factories producing the same good, there are various degrees of vertical integration within each factory. However, Smith does not investigate why such variation would occur. ${ }^{66}$ Indeed, Smith leaves many questions unanswered. If putting the pins in paper is "a trade by itself," why does the firm have an employee do it instead of contracting with a putting-pins-in-paper firm? The first man in the factory draws out the wire, which came from a metal ingot. Where did the metal ingot come from and why doesn't the factory also make the ingot?

Coase attempts to answer these questions. He notes that market transactions are costly. ${ }^{67}$ Smith's pin factory has "eighteen distinct operations." 68 If each of these operations were performed by separate firms, the pin seller would have to discover the appropriate price to pay for each input and the contribution of that input to the seller's profits. Is placing the head on the pin more or less valuable than putting the pins in paper? An integrated firm does not have to ask that question. Also, the pin seller would have to negotiate, monitor, and enforce contracts with as many as eighteen different suppliers. If each operation is critical to the production of a pin, then each supplier can hold out for more favorable terms of trade. An integrated firm does not have such worries and does not face these costs. Coase's entrepreneur directs employees to perform each task and can arrange tasks among employees that maximize the entrepreneur's profit. ${ }^{69}$ It is for this reason that some have characterized the firm as an organization run by command and control in contrast to a

63. Id.

64. See id.

65. Id.

66. See id.

67. Coase, supra note 58, at 390 ("The main reason why it is profitable to establish a firm would seem to be that there is a cost of using the price mechanism.").

68. SмITH, supra note 62 , at 3 .

69. Coase, supra note 58, at 388 ("Within a firm, these market transactions are eliminated and in place of the complicated market structure with exchange transactions is substituted the entrepreneurco-ordinator, who directs production."). 
market governed by voluntary exchange. ${ }^{70}$

Coase also observes the limits to vertical integration. In particular, there may be limits to his entrepreneur's resources or abilities, such that adding an additional transaction within the firm would generate decreasing returns. $^{71}$ "Naturally, a point must be reached where the costs of organizing an extra transaction within the firm are equal to the costs involved in carrying out the transaction in the open market, or, to the costs of organizing by another entrepreneur." 72

In this way, Coase addresses the question of where the pin factory's metal ingot came from. If the factory bought the ingot from a metalworker, then the costs of making the ingot in house were greater than costs associated with negotiating a supply agreement with a metalworker. On the other hand, if the factory made the ingot, then the costs of production were lower than costs of a market transaction. For example, by the 18 th century, metalworking and wiredrawing were somewhat mechanized and a metalworker might have vertically integrated into wiredrawing and then into the manufacture of pins. ${ }^{73}$

Coase notes that when one firm vertically integrates with another, the firm may acquire its partner's entire business and not just a single operation: "If $A$ therefore wishes to avoid a market transaction, he will have to take over all the processes of production controlled by $B .{ }^{.74}$ For example, a wire maker who buys a metalworking firm would also acquire the metalworker's business that makes metal sheet and plate. But the costs of managing these additional lines of business could exceed the benefits of vertically integrating the ingot/wiredrawing process. Coase's analysis of the "make-or-buy" decision can be summarized as choice between balancing the costs of using the price mechanism and the costs of contracting against the cost of internal organization. ${ }^{75}$

\footnotetext{
70. See, e.g., Armen A. Alchian \& Harold Demsetz, Production, Information Costs, and Economic Organization, 62 AM. ECON. REV. 777, 777 (1972) ("It is common to see the firm characterized by the power to settle issues by fiat, by authority, or by disciplinary action superior to that available in the conventional market. This is delusion.").

71. Coase, supra note 58, at 394.

72. Id.

73. Brian D. Newbury \& Michael R. Notis, The History and Evolution of Wiredrawing Techniques, 56 JOM 33, 37 (2004).

74. Coase, supra note 58 , at 395.

75. Id. at 394-95.
} 


\section{B. The Complexities That Undermine the Functional Equivalence of Contract and Merger}

Armen Alchian and Harold Demsetz extend Coase's ideas. ${ }^{76}$ First, however, they dispense with the notion that a firm is characterized as an organization ruled by the diktat of the owner-manager as "delusion." 77 They note that many firms do not own their inputs - especially labor-and cannot move them around like chess pieces. ${ }^{78}$

Telling an employee to type this letter rather than to file that document is like my telling a grocer to sell me this brand of tuna rather than that brand of bread. I have no contract to continue to purchase from the grocer and neither the employer nor the employee is bound by any contractual obligations to continue their relationship. Long-term contracts between employer and employee are not the essence of the organization we call a firm. ${ }^{79}$

Coase's approach focused on differences in transaction costs to explain whether a firm relied on the price system or intra-firm decision making. ${ }^{80}$

Alchian and Demsetz conclude that firms have a fundamentally different production function from separate, additive market-based production - and that cooperative team-based production could be much more efficient. ${ }^{81}$ Smith notes that if the ten employees in the pin factory "wrought separately and independently," fewer than 200 pins would be produced in a day, but organized as a team they produced more than 48,000 pins a day. ${ }^{82}$

George Stigler observes some activities are subject to increasing returns to scale and asks why the firm does not therefore exploit those returns to become a monopoly. ${ }^{83} \mathrm{He}$ answers that some activities are subject to decreasing returns to scale and the opposing forces of increasing and decreasing returns limits the size of the firm. ${ }^{84}$ In Stigler's model, often called the industry life cycle, firms in an industry begin with vertical integration as the market may be too small to support specialized firms

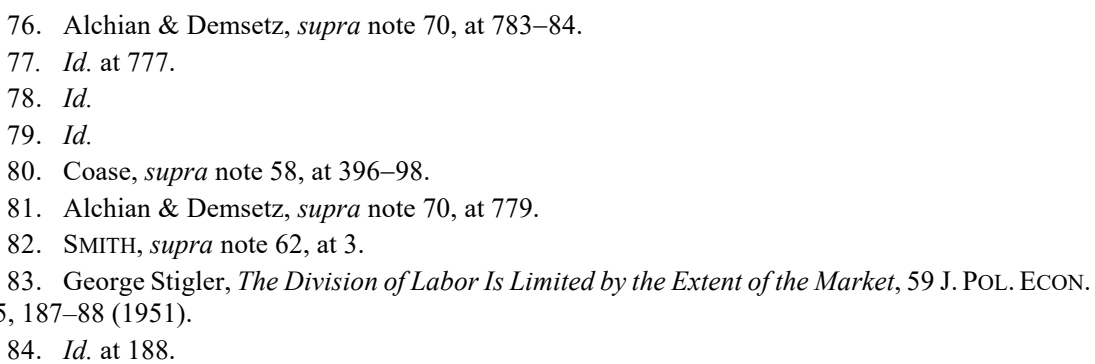


producing an intermediate input. ${ }^{85}$ Over time, both the industry and firms grow. ${ }^{86}$ At some point, as the markets for intermediate goods mature, specialized firms emerge and the vertically integrated firm spins off or outsources some processes. ${ }^{87}$ As an industry declines, shrinking markets for intermediate goods may cause the remaining firms to re-integrate these processes. ${ }^{88}$ Thus, in Stigler's model, the degree of vertical integration is a dynamic interaction among the firm's economies of scale as well as the extent of the firm's market and the market for its inputs. ${ }^{89}$

Importantly, Alchian and Demsetz conclude that one of the key diseconomies of scale comes from the transaction costs associated with gathering and using information. ${ }^{90}$ Most of these information costs involve monitoring, measuring, and rewarding the performance of cooperating resources, which they describe as metering resources:

[S]ince costs must be incurred to monitor each other, each input owner will have more incentive to shirk when he works as part of a team, than if his performance could be monitored easily or if he did not work as a team. If there is a net increase in productivity available by team production, net of the metering cost associated with disciplining the team, then team production will be relied upon rather than a multitude of bilateral exchange of separable individual outputs. ${ }^{91}$

The costs of metering are complicated by the jointness of production. Alchian and Demsetz provide the hypothetical of two workers jointly lifting heavy cargo into trucks. ${ }^{92}$ The manager cannot determine each worker's contribution to the task simply by looking at the total weight loaded in a day: because it is a team effort, by definition it is not the sum of the separable outputs of each worker. ${ }^{93}$

Alchian and Demsetz develop a model of the organization of a firm from these two foundations: (1) team production as an essential condition for a firm and (2) costly metering of the team and other resources. ${ }^{94}$ Managers emerge from a need to meter teams and other resources, with managers' incentives to be productive and effective driven by sharing the

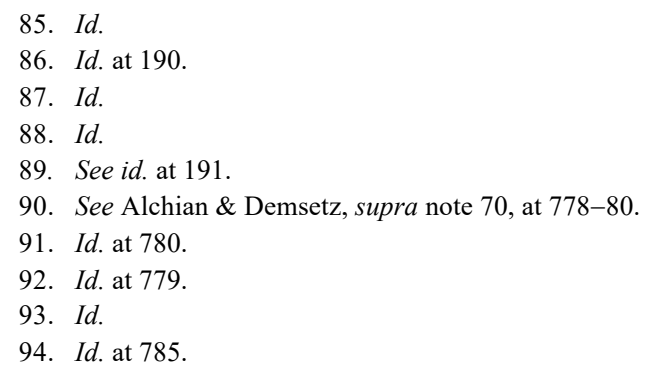


residual income associated with their teams. ${ }^{95}$ The various degrees of vertical integration across organizations thus reflect variations in the efficiency of team production, variations in the extent and cost of market alternatives, and variations in the costs of metering. ${ }^{96}$

Oliver Williamson largely agrees with Alchian and Demsetz's assessment of team production. ${ }^{97}$ However, he argues that separable production processes are widespread and "intermediate product market transactions are much more numerous than conventional wisdom would suggest." 98 Thus, he concludes that metering team production may be an important function performed by a firm, but is not an essential condition for the firm. ${ }^{99}$ Instead, he argues that the extent of asset specificity is key to a firm's make-or-buy decision. ${ }^{100}$

For Williamson, asset specificity includes durable specialized investments or general assets that are very costly to relocate or redeploy. ${ }^{101}$ As asset specificity increases, the cost of contracting - and the costs associated with incomplete contracts - increases. ${ }^{102} \mathrm{He}$ concludes that greater asset specificity would be associated with greater integration within a firm. Indeed, transaction costs arising from asset specificity are a common source of the decision to vertically integrate. ${ }^{103}$ Williamson's model also hypothesizes that, because of economies of scale, larger firms will be more integrated into the production of inputs than will smaller firms, which is consistent with Stigler's industry life cycle model. ${ }^{104}$

Benjamin Klein, Robert Crawford, and Alchian provide empirical evidence for the importance of asset specificity in vertical integration. ${ }^{105}$ They conclude that incomplete contracting and asset specificity can make vertical integration more efficient than competitive contracting. ${ }^{106}$

\footnotetext{
95. Id. at $782-83$.

96. See id. at 795 .

97. See generally Oliver E. Williamson, The ECONOMic Institutions of CAPitalism 85-102 (1985) (discussing transaction costs and the strategic purposes behind vertical integration).

98. Id. at 87.

99. Id. at 88 n. 44 .

100. Id. at 89 .

101. Id. at $95-96$.

102. Id.

103. See Paul L. Joskow, Vertical Integration, 55 ANTITRUST BULL. 543, 563 (2010) (“Contractual incompleteness, and its interaction with the attributes of different types of transactional attributes including asset specificity, complexity, uncertainty, and other attributes play a central role in the evaluation of the relative costs of governance through market-based bilateral contracts versus governance through vertical integration.").

104. Id. at 561-62.

105. Benjamin Klein et al., Vertical Integration, Appropriable Rents, and the Competitive Contracting Process, 21 J.L. ECON. 297, 298 (1978).

106. Id. at 306-07.
} 
Contracts are incomplete because of the costs of negotiating, monitoring, and enforcing contractual terms in the face of uncertainty. ${ }^{107}$ This can lead to opportunistic behavior and the appropriation of quasi-rents from the specific asset. ${ }^{108}$ This risk of appropriation of quasi-rents can be inefficient if it means that value-increasing investments are not made, or if a less efficient investment is made to protect against appropriation or opportunistic behavior. ${ }^{109}$

Klein, Crawford, and Alchian provide evidence from General Motor's relationship with Fisher Body in the 1920s. ${ }^{110}$ In 1919, GM entered into a ten-year contractual agreement with Fisher in which GM would purchase nearly all of its closed automobile bodies from Fisher. ${ }^{111}$ As auto body manufacture shifted from wood to metal, Fisher required assets specialized for GM's design. ${ }^{112}$ During the term of the agreement, demand for GM's autos increased by more than projected by the parties at the time of the agreement. $^{113} \mathrm{GM}$ became dissatisfied with the pricing terms of the agreement in the face of increased demand. ${ }^{114}$ In particular, Fisher could act opportunistically by demanding higher prices than those articulated in the contract: GM could not obtain auto bodies from other sources on short notice, and halting assembly was extremely costly. ${ }^{115}$ In addition, GM pressed Fisher to locate its body plants adjacent to GM's assembly plants to reduce transportation and inventory costs. ${ }^{116}$ Fisher, however, resisted. ${ }^{117}$ In 1924, GM began buying Fisher stock and completed a merger with Fisher in $1926 .^{118}$

As Klein, Crawford, and Alchian conclude:

[A]s we move toward more complex ownership relationships the problem of efficiently structuring the economic relationship, either within the firm or via contracts, also becomes highly complex. Stating that the world is complicated is another way of admitting our ignorance. However, explicitly recognizing that contracting costs are not zero, as they are often implicitly assumed to be in economic analysis, and explicitly considering the determinants of these costs (such as the

\footnotetext{
107. Id. at 301 .

108. Id.

109. Id. at 301-02.

110. Id. at 308-10.

111. Id. at 308-09.

112. Id. at 308 .

113. Id. at 309 .

114. Id.

115. Id.

116. Id. at 309-10.

117. Id.

118. Id. at 310 .
} 
presence of appropriable quasi rents) is the first step in explaining the large variety of contractual and ownership arrangements we observe in the real world. ${ }^{119}$

While many functions can be performed either by contract across firms or by a single, integrated firm internally, the complex reality is that the two are not always functionally interchangeable, nor do they always impose the same risks and costs or allocate them the same way.

\section{THE FUNDAMENTAL (AND IMPORTANT) DIFFERENCE BETWEEN VERTICAL AND HORIZONTAL MERGERS}

The organizational and contractual complexities that underlie the choice between merger and contract are fundamental to understanding the conduct of firms and the likely competitive effects of their behavior. As we discuss above, ${ }^{120}$ the assumption by some critics that contract and merger are functional equivalents is at odds with the fundamental economics of vertical relationships. But that same complexity also undermines the assumption that horizontal and vertical mergers impose competitive threats by the same mechanism - and with a similar level of risk - and should therefore be given similar enforcement attention, both in kind and in intensity.

Recent former FTC Bureau of Competition Director, Bruce Hoffman, lays out the extensive and fundamental differences between horizontal and vertical mergers in a compelling 2018 talk. ${ }^{121}$ Of particular importance:

Horizontal mergers combine competitors. By definition, a merger of competitors directly and necessarily reduces competition by eliminating a substitute. There is a strong theoretical basis for horizontal enforcement because economic models predict at least nominal potential for anticompetitive effects due to elimination of horizontal competition between substitutes.

In contrast, vertical mergers do not combine substitutes, and in fact often involve complements, such as a product plus distribution or a critical input to a complex device. Where horizontal mergers reduce competition on their face-though that reduction could be minimal or more than offset by benefits-vertical mergers do not. Instead, to determine whether a vertical merger threatens competitive harm requires predictions about the post-merger conduct of the merged firm where theoretical predictions are ambiguous. As Professor Steve Salop has catalogued, and as I discuss in more detail in a few minutes, there

119. Id. at 325 .

120. See supra Part II.

121. Hoffman, supra note 1, at 2-3. 
are plenty of theories of anticompetitive harm from vertical mergers. But the problem is that those theories don't generally predict harm from vertical mergers; they simply show that harm is possible under certain conditions.

Moreover, while efficiencies are often important in horizontal mergers, they are much more intrinsic to a vertical transaction due to the cost-reducing effects of most vertical mergers, at least in the abstract. Due to the elimination of double-marginalization and the resulting downward pressure on prices, vertical mergers come with a more builtin likelihood of improving competition than horizontal mergers.

Unfortunately, compared to horizontal mergers, there are also fewer quantitative theoretical models that we can use to attempt to predict outcomes in vertical scenarios, and the models that exist have a far ${ }_{122}$ shorter track record than those used in assessing horizontal mergers. . .

\section{A. Indirect Competitors Are Different Than Actual Competitors}

Salop and other critics of the current state of vertical merger enforcement, on the other hand, assert that because the eventual effect of a vertical merger is a "horizontal" one, the two types of mergers should be treated in essence the same way. ${ }^{123}$ According to Salop, "For the type of markets that are normally analyzed in antitrust, the competitive harms from vertical mergers are just as intrinsic as are harms from horizontal mergers." 124 Thus, a vertically integrated firm faces an "intrinsic incentive" $" 125$ to foreclose downstream competition "by raising the input price it charges to the rivals of its downstream merger partner" in the same way that horizontal firms face an "inherent upward pricing pressure from horizontal mergers in differentiated products markets, even without coordination." $" 126$

But an "intrinsic harm" and an "intrinsic incentive" are not the same thing. In particular, an "intrinsic incentive" to foreclose competition in the vertical context still requires a decision - and the ability - to execute upon the incentive in a contractual relationship with non-integrated downstream firms. By contrast, the pressure faced by horizontal competitors requires no coordination and is imposed by consumers rather than through directed

122. Id. (emphasis added).

123. Salop, Invigorating, supra note 4, at 1972.

124. Id. (emphasis added).

125. Id. at 1973 (emphasis added).

126. Id. (emphasis added). 
conduct by a competitor. In the limit case, the horizontal competitor that does not respond to pricing pressure from a competitor (even a differentiated one) will go out of business; the vertical firm that does not raise input prices to differentiated downstream rivals will not face this same existential threat.

In an implicit acknowledgement of this distinction, Salop actually describes the competition between an upstream firm and a downstream partner as indirect: "the upstream merging firm that supplies a downstream firm is inherently an 'indirect competitor' of the future downstream merging firm. That indirect competition is eliminated by merger. This unilateral effect is exactly parallel to the unilateral effect from a horizontal merger." 127 But of course, the two are not "exactly parallel."

To the extent that removal of a vertical indirect (or potential) competitor is deemed analogous to horizontal competition, any analysis of that situation would have to account for the difference in effect between removing an existing, direct competitor and an indirect or potential one. Indirect competition is not the same as direct competition. Even in Salop's telling, the mechanism by which it operates requires that the firm have market power and that, post-merger, the firm raises costs to the downstream firm's horizontal rivals. While this is possible, of course, it is not guaranteed, and, at the very least, would have to be conditioned by the likelihood of it occurring. A horizontal competitor, on the other hand, operates as an immediate and present constraint, the effect of the removal of which is not conditioned on further action by the merged firm. The size of the effect may be (and often is) small. But the effect is automatic.

Furthermore, it is not actually the case that the incentive to foreclose downstream rivals is "intrinsic," nor is it the case that the effect is deleterious:

However, there is no general incentive to raise rivals' costs, and even when it is privately profitable to do so, the attendant welfare consequences may be positive. If the cost raising strategy is profitable, it may lead to an increase or decrease in price. This is because the dominant firm may expand output enough to offset the contraction in the output of the fringe. If the strategy leads to an increase in price, total welfare still may rise if the dominant firm is more efficient than the fringe firms, as the shift in output from the fringe to the dominant firm can increase productive efficiency. ${ }^{128}$

It is true that, to the extent that a pre-merger upstream firm could merge with a rival instead of the target firm, or could facilitate entry by a

127. FTC Hearing \#5 Presentation Slides, supra note 10, at 15.

128. Cooper et al., supra note 1, at 643 . 
new downstream rival, it can operate as a constraint on the merging firm. And, indeed, potential competitors are important constraints on existing market actors. But by definition, they do not offer the same degree of constraint as existing, actual competitors. Rather, any analysis of their competitive effect would have to incorporate the probability of entry. Moreover, such analysis would have to differentiate between entry that is deterred because of increased competition and anticompetitive foreclosure:

Many models of vertical practices find that competitors are excluded precisely because the practices in question intensify competition. Antitrust policymakers tempted to draw policy inferences from these analyses always must bear in mind that harm to competitors ... is not the same as harm to competition. Instead, harm to competitors is oftenindeed, usually - consistent with enhanced competition. ${ }^{129}$

High-quality analysis of the effects of potential competition are few and far between. But, according to several studies, a potential competitor may have on the order of one-quarter percent to two percent the effect on competition as an actual competitor. ${ }^{130}$

Furthermore, any efficiency gains from a horizontal merger are not automatic and must be established. On the other hand, the realization of vertical merger efficiencies resulting from the elimination of double marginalization at least is automatic:

Some horizontal mergers do not create efficiencies; they are profitable only because of the post-merger anticompetitive conduct made possible by the transaction.

By contrast, the primary lesson of both the older literature on vertical integration, as well as the newer "post-Chicago" literature, is that this trade-off invariably exists for all vertical transactions that threaten to reduce consumer welfare. ${ }^{131}$

\footnotetext{
129. Id. at 647 .
}

130. See John Kwoka, Mergers That Eliminate Potential Competition, in RESEARCH HANDBOOK ON THE ECONOMICS OF ANTITRUST LAWS (Einer Elhauge ed., 2012) ("All twelve studies [of airline markets] find that potential competition results in lower prices by incumbent carriers, in ten cases by statistically significant amounts. Except as noted below, the amounts range between one quarter of one percent to about two percent, and in all cases are less than the amount of the price decline from one additional actual competitor, specifically, from one eighth to one third as large.").

131. Reiffen \& Vita, supra note 3, at 920 (commenting on Riordan \& Salop, Evaluating Vertical Mergers, supra note 27); see also Joseph J. Spengler, Vertical Integration and Antitrust Policy, $58 \mathrm{~J}$. POL. ECON. 347, 347 (1950) ("Horizontal integration may, and frequently does, make for higher prices and a less satisfactory allocation of resources than does pure or workable competition. Vertical integration, on the contrary, does not, as such, serve to reduce competition and may, if the economy 
The logic is simple: Potentially welfare-reducing vertical mergers are those that involve an upstream firm with market power. Thus, pre-merger, all downstream firms bear presumptively higher input costs, and, in order to realize their own profit, must increase final product prices to consumers by even more. ${ }^{132}$ But after the merger, the merged downstream entity no longer pays the markup. As a result, it "enjoys lower input costs and thus increases its output, thereby increasing welfare." 133 At the same time, of course, non-merged downstream firms bear a higher input price, and it is an empirical question whether the net consumer welfare effect is positive or negative. ${ }^{134}$ But it is never a question that the two effects operate simultaneously and that the reduction of double marginalization necessarily occurs. Indeed, it is most likely to arise and to lead to net consumer welfare benefits precisely where there is the greatest potential for anticompetitive price increases to downstream rivals:

High price-cost margins increase the size of the efficiency gain to the integrated firm as well as the potential for anticompetitive input price increases.... [And] the post-Chicago literature suggests that vertical mergers that occur in the presence of high premerger concentration are likely to result in lower prices to consumers. ${ }^{135}$

All else equal, the effect of removing a horizontal competitor by merger is automatic: less competition. That is not necessarily bad; it may be compensated for and it may also enable innovation, more competition, or other results that benefit consumers. But, in the first instance, former head-to-head competitors that merge are no longer competing. With vertical mergers, however, the effect is not to automatically reduce competition (indirect, potential, or otherwise). A vertically integrated firm might choose to hurt unaffiliated downstream competitors by more than it benefits its integrated downstream firm, but nothing is automatic. Assessing the competitive effect of such a merger necessarily means incorporating an added layer of uncertainty, complexity, and distance between cause and effect. And, in the absence of a few particular, tenuous, and stylized circumstances, "[i]n this model, vertical integration is unambiguously good for consumers.",136

\footnotetext{
is already ridden by deviations from competition, operate to intensify competition."); ROBERT H.

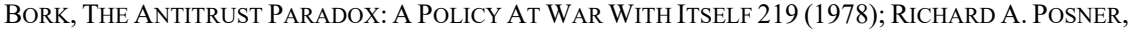
ANTITRUST LAW 228 (1976).

132. See, e.g., Michael A. Salinger, Vertical Mergers and Market Foreclosure, 103 Q.J. ECON. 345,349 (1988).

133. Reiffen \& Vita, supra note 3, at 921.

134. Id. at $918-24$.

135. Id. at 921 .

136. Cooper et al., supra note 1, at 644.
} 
In response, proponents of invigorated vertical merger enforcement argue in part that:

[T] he claim that vertical mergers are inherently unlikely to raise horizontal concerns fails to recognize that all theories of harm from vertical mergers posit a horizontal interaction that is the ultimate source of harm. Vertical mergers create an inherent exclusionary incentive as well as the potential for coordinated effects similar to those that occur in horizontal mergers. ${ }^{137}$

But this fails to resolve anything, and the "analogy with horizontal mergers is misleading." 138 It is uncontroversial (and far from "[un]recognized") that "all theories of harm from vertical mergers posit a horizontal interaction that is the ultimate source of harm." "All this says is that there could be harm of the sort horizontal mergers might cause. But it does not acknowledge that the likelihood and extent of that harm are different in the vertical and horizontal contexts. Moreover, it does not note that the mechanism by which harm might arise is different and more complex in the vertical case. All in all, the probability of that outcome is lower in the case of a vertical merger where it is dependent on an additional step that may or may not arrive and that may or may not cause harm.

\section{B. Empirical Evidence Continues to Support the Presumption That Vertical Mergers Are Procompetitive or Competitively Benign}

Critics of the "Chicago school orthodoxy" on vertical mergers pay special attention to "oligopoly" markets, ${ }^{140}$ contending that "[a] stronger overarching procompetitive presumption for vertical mergers does not make sense in oligopoly markets where vertical merger enforcement would be focused." "141 But, based on the empirical evidence, the critics are simply wrong that the evidence supports greater condemnation of vertical mergers, even in oligopoly markets. At best, the evidence from oligopoly

137. Baker et al., supra note 9, at 13 (emphasis added).

138. Reiffen \& Vita, supra note 3 , at 920.

139. Baker et al., supra note 9, at 13; see also Cooper et al., supra note 1, at 642-45 (assessing the vast majority of post-Chicago theories of vertical harm under the sub-heading "Softening horizontal competition").

140. See Baker et al., supra note 9, at 13 ("[T]reat[ing] vertical mergers more permissively than horizontal mergers, even in concentrated markets, ... . would be tantamount to presuming that vertical mergers benefit competition regardless of market structure. However, such a presumption is not warranted for vertical mergers in the oligopoly markets that typically prompt enforcement agency review."); FTC Hearing \#5 Transcript, supra note 21, at 14-15 (statement of Steven Salop, Professor, Georgetown University Law Center); see also Cooper et al., supra note 1, at 642-48 (discussing such "post-Chicago" scholarship).

141. FTC Hearing \#5 Presentation Slides, supra note 10, at 14. 
markets is mixed. This suggests, not a rush to condemnation, but instead a need for further research. Particularly, before any new policies are based on such ambivalent (at best) evidence.

These criticisms either must ignore or dismiss the hundreds of econometric studies famously reviewed by Lafontaine and Slade. ${ }^{142}$ Indeed, typically this longstanding work is criticized as irrelevant or insufficient. ${ }^{143}$ But the reality is that these studies still constitute the overwhelming majority of the evidence we have; and many, if not most, of the studies are perfectly well done, even by modern standards. ${ }^{144}$ The upshot of these studies, as Lafontaine and Slade put it, is that, "consistent with the large set of efficiency motives for vertical mergers that we have described so far, the evidence on the consequences of vertical mergers suggests that consumers mostly benefit from mergers that firms undertake voluntarily." 145

Lafontaine, while acknowledging the limitations of some of the evidence used for these studies, recently reiterated the relevance of the studies to vertical mergers and restated the overall conclusions of the literature:

We were clear that some of the early empirical evidence is less than ideal, in terms of data and methods.

But we summarized by saying that the empirical literature reveals consistent evidence of efficiencies associated with the use of vertical restraints (when chosen by market participants) and, similarly, with vertical integration decisions. ${ }^{146}$

Slade also reiterated this same conclusion in June 2019 at the Organization for Economic Cooperation and Development, where she noted that, even in light of further studies, "[t]he empirical evidence leads

142. See Francine Lafontaine \& Margaret Slade, Vertical Integration and Firm Boundaries: The Evidence, 45 J. ECON. LITERATURE 629 (2007); see also Cooper et al., supra note 1, at 648 n.25; Margaret E. Slade, The Effects of Vertical Restraints: An Evidence Based Approach, in REPORT: THE PROS AND CONS OF VerTiCAL RESTRAINTS 12, 22 (2008) ("[Table 1 in this paper] indicates that voluntarily adopted restraints are associated with lower costs, greater consumption, higher stock returns, and better chances of survival.").

143. See, e.g., FTC Hearing \#5 Presentation Slides, supra note 10, at 25 (dismissing Lafontaine \& Slade and attempting to adduce a few newer studies as contradictory and dispositive).

144. It is fair to point out that, indeed, many of the studies look at the effects of vertical restraints rather than vertical mergers per se. But such studies are, of course, instructive given that the theories of harm arising from vertical mergers arise from precisely the sorts of conduct at issue in these studies. If perfect alignment of facts were required, no economic theory or evidence would ever be relevant.

145. Lafontaine \& Slade, supra note 142, at 663.

146. FTC Hearing \#5 Presentation Slides, supra note 10, at 93 (slides by Francine Lafontaine, Professor, Michigan-Ross). 
one to conclude that most vertical mergers are efficient." 147 Moreover, Slade noted that forecasting likely effects from vertical mergers using more modern tools, like assessment of vertical upward pricing pressure, is a fraught and unreliable endeavor. ${ }^{148}$ Regarding the AT\&T-Time Warner merger, in particular, Slade remarks:

All of my comments are especially applicable to mergers in the technology, media, and telecom sectors. In particular those mergers usually involve many products both up and downstream, some of which might be susceptible to foreclosure and others which might not be. For example, before the contested merger between AT\&T and Time Warner, Time Warner owned many content providers . . each of which provided many products, and AT\&T distributed video programming and had millions of direct to consumer relationships as well as high speed networks. Forecasting the effects of such a complex transaction using vGUPPIs and EDM alone would be subject to many type 1 and 2 errors. Furthermore, the US Justice Department focused on the merged firm's increased bargaining leverage, and vGUPPIs do not incorporate bargaining between up and downstream firms. ${ }^{149}$

In response, critics point to many newer studies, claiming these studies demonstrate harm from vertical mergers: "Surveys of earlier economic studies, relied upon by commenters who propose a procompetitive presumption, reference studies of vertical mergers in which the researchers sometimes identified competitive harm and sometimes did not. However, recent empirical work using the most advanced empirical toolkit often finds evidence of anticompetitive effects." 150

The implication is that the balance of evidence taken from these studies tips the scales against a presumption of benefits from vertical mergers. Yet the newer literature is no different than the old in finding widely procompetitive results overall, intermixed with relatively few seemingly harmful results. As scholars at the Global Antitrust Institute at George Mason Law School have noted in a thorough canvassing of the more recent literature:

In sum, these papers from 2009-2018 continue to support the conclusions from Lafontaine \& Slade (2007) and Cooper et al. (2005) that consumers mostly benefit from vertical integration. While vertical integration can certainly foreclose rivals in theory, there is only limited

147. Margaret E. Slade, Vertical Integration and Mergers: Empirical Evidence and Evaluation Methods, Prepared for the Panel on Vertical Mergers in the Technology, Media, and Telecom Sectors, OECD Competition Committee Meeting, ORG. FOR ECON. COOPERATION \& DEV. 9 (June 7, 2019), https://one.oecd.org/document/DAF/COMP/WD(2019)68/en/pdf [https://perma.cc/CEB5-Q7QJ].

148. Id. at $9-13$.

149. Id. at 13 .

150. Baker et al., supra note 9, at 14 . 
empirical evidence supporting that finding in real markets. ${ }^{151}$

Below, we briefly review the actual results of several of these recent studies, including, in particular, studies that were referenced at the recent FTC Hearings to support claims that the "econometric evidence does not support a stronger procompetitive presumption."152

\section{Luco and Marshall}

Fernando Luco and Guillermo Marshall examined Coca-Cola and PepsiCo acquisitions of some of their downstream bottlers. ${ }^{153}$ At the time, Dr Pepper Snapple Group "remained independent in selling inputs to bottlers." 154 Bottlers, even those that were vertically integrated with one of their upstream suppliers, purchased inputs from competing upstream suppliers. ${ }^{155}$ Based on their statistical analysis, the authors concluded that vertical integration in the carbonated-beverage industry was associated with price increases for Dr Pepper Snapple Group products and price decreases for both Coca-Cola and PepsiCo products bottled by vertically integrated bottlers. ${ }^{156}$ However, the market share of the products associated with higher prices was no more than two percent. Thus, the authors conclude: "vertical integration did not have a significant effect on quantity-weighted prices when considering the full set of products . . ."157

It could be argued that certain members of "targeted customer" markets experienced harm from the vertical merger. Salop provides an example of 7-Up and Dr Pepper consumers, which raises the question: what is the relevant market? ${ }^{158}$ For example, 7-Up is likely a close substitute for Sprite (Coca-Cola) and Sierra Mist (PepsiCo), and Dr Pepper is likely a close substitute for Pibb Xtra (formerly Mr. Pibb, a Coca-Cola product). In the face of consumer substitution, it is not clear whether the

151. Glob. Antitrust Inst., Antonin Scalia Law Sch., Comment Submitted in the Federal Trade Commission's Hearings on Competition and Consumer Protection in the 21st Century, Vertical Mergers (Sept. 6, 2018), https://gai.gmu.edu/wp-content/uploads/sites/27/2018/09/GAI-Comment-on -Vertical-Mergers.pdf [https://perma.cc/DZ5G-PZXB].

152. FTC Hearing \#5 Presentation Slides, supra note 10, at 25. For a more comprehensive assessment of the recent empirical scholarship (finding the same overall results that we do), see id.

153. Fernando Luco \& Guillermo Marshall, Vertical Integration With Multiproduct Firms: When Eliminating Double Marginalization May Hurt Consumers 1, 2 (Jan. 15, 2018), https://papers.ssrn.com/sol3/papers.cfm?abstract_id=3110038 [https://perma.cc/EWG3-YYFE].

154. Id. at 3 .

155. Id. at 3-4.

156. Id. at 4 .

157. Id. at 22 .

158. FTC Hearing \#5 Transcript, supra note 21, at 34-35 (statement of Steven Salop, Professor, Georgetown University Law Center). 
relevant consumers experienced any measurable harm, even in the face of the estimated price increases.

The paper in fact demonstrates that vertical integration did not create harm in the cases studied. The price of Coke and Pepsi went down and the cost to some rivals increased, ${ }^{159}$ but, overall, the effect on consumers was either an efficiency gain or no change. ${ }^{160}$ As Francine Lafontaine noted, "in total, [Coke and Pepsi] consumers were better off given who was consuming how much of what." 161

\section{Hastings and Gilbert}

Justine Hastings and Richard Gilbert concluded that vertical integration is associated with statistically significant higher wholesale gasoline prices. ${ }^{162}$ Using data from 1996 to 1998 , their study examined the wholesale prices charged by a vertically integrated refiner/retailer and found the firm charged higher wholesale prices in cities where its retail outlets competed more with independent gas stations. ${ }^{163}$ Hastings and Gilbert concluded that their observations are consistent with a theory of raising rivals' costs. ${ }^{164}$

In subsequent research, Christopher Taylor, Nicolas Kreisle, and Paul Zimmerman examined retail gasoline prices following the 1997 acquisition of an independent gasoline retailer by a vertically integrated refiner/retailer. ${ }^{165}$ They estimated the merger was associated with a price increase of 0.4 to 1.0 cent per gallon - about one percent or less - and was economically insignificant. ${ }^{166}$ These results were at odds with Hastings' earlier review of the same merger which concluded that the replacement of independent retailers with branded vertically integrated retailers would result in higher prices. ${ }^{167}$

To explain the conflicting results between Hastings and Taylor et al., Hastings highlighted the challenges of evaluating vertical mergers with

\footnotetext{
159. Id. at 88 (statement of Francine Lafontaine, Professor, Michigan Ross).

160. Id.

161. Id. at $88-89$.

162. Justine S. Hastings \& Richard J. Gilbert, Market Power, Vertical Integration and the Wholesale Price of Gasoline, 53 J. INDUS. ECON. 469, 490 (2005).

163. Id. at $473-74$.

164. Id. at 490 .

165. Christopher T. Taylor, Nicolas M. Kreisle \& Paul R. Zimmerman, Vertical Relationships and Competition in Retail Gasoline Markets: Empirical Evidence from Contract Changes in Southern California: Comment, 100 AM. ECON. REv. 1269, 1269 (2010).

166. Id. at $1272-76$.

167. Id. at 1269 (comparing study results with results from Justine Hastings, Vertical Relationships and Competition in Retail Gasoline Markets: Empirical Evidence from Contract Changes in Southern California, 94 AM. ECON. REV. 317 (2004)).
} 
incomplete data or using different sets of data - even seemingly similar data can yield wildly different results. ${ }^{168}$ Because of the wide range of reported results and their sensitivity to the data used, caution should be exercised before inferring any general conclusions from this line of research.

Other commonly cited studies - referenced for the proposition that the more recent evidence on vertical mergers shows a greater likelihood of harm-fare no better.

\section{Crawford et al.}

Gregory Crawford, Robin Lee, Michael Whinston, and Ali Yurukoglu examined vertical mergers between cable multichannel video programming distributors (MVPDs) and regional sports networks (RSNs). ${ }^{169}$ Margaret Slade characterizes the findings of the paper as mixed because vertical integration can be associated with both beneficial and harmful effects. ${ }^{170}$ And, in a purely semantic sense, that is an accurate characterization. But the overall results in Crawford et al. overwhelmingly found procompetitive consumer welfare effects:

In counterfactual simulations that enforce program access rules, we find that vertical integration leads to significant gains in both consumer and aggregate welfare. ... Averaging results across channels, we find that integration of a single RSN with effective program access rules in place would reduce average cable prices by $1.2 \%(\$ 0.67)$ per subscriber per month in markets served by the RSN, and increase overall carriage of the RSN by $9.4 \%$. Combined, these effects would yield, on average, a $\$ 0.43$ increase in total welfare per household from all television services, representing approximately $17 \%$ of the average consumer willingness to pay for a single RSN. We also predict that consumer welfare would increase.

On net, we find that the overall effect of vertical integration in the absence of effective program access rules-allowing for both efficiency and foreclosure incentives - is to increase consumer and total welfare on average, resulting in (statistically significant) gains of approximately \$0.38-0.39 per household per month, representing $15-16 \%$ of the

168. Justine S. Hastings, Vertical Relationships and Competition in Retail Gasoline Markets: Empirical Evidence from Contract Changes in Southern California: Reply, 100 AM. ECON. REv. 1277, $1277-78$ (2010).

169. Gregory S. Crawford et al., The Welfare Effects of Vertical Integration in Multichannel Television Markets, 86 ECONOMETRICA 891, 892 (2018).

170. Slade, supra, note 147, at 6. 
average consumer willingness to pay for an RSN. . . ${ }^{171}$

Their results are sensitive to the presence of program access rules. ${ }^{172}$ These rules ensure that non-integrated rival distributors have access to content from an integrated provider. ${ }^{173}$ Crawford et al. concluded that the absence of enforced program access rules reduce some of the consumer welfare benefits. ${ }^{174}$

Nevertheless, the implications of this well-designed and carefully executed study are clear. Indeed, here is how Harvard economist, Robin Lee, one of the study's authors, recently characterized the results:

[O]ur key findings are that, on average, across channels and simulations, there is a net consumer welfare gain from integration. Don't get me wrong, there are significant foreclosure effects, and rival distributors are harmed, but these negative effects are oftentimes offset by sizeable efficiency gains. Of course, this is an average. It masks considerable heterogeneity. When complete exclusion occurs, which happens both in our simulations and in the data some of the times, consumer welfare is actually harmed. ${ }^{175}$

Two things are particularly notable about the findings of this paper. First, the paper properly offers the caveat - notably missing from Salop's and others' overly-confident assertions regarding vertical merger welfare effects - that its results do not include possible dynamic effects. ${ }^{176}$ In particular, the authors note that their model cannot account for investment decisions made by MVPDs or RSNs in the face of increased vertical integration. ${ }^{177}$

Any conclusion regarding the consumer welfare effects from vertical integration is unreliable as a policy guide if it does not consider, for example, the corresponding investment effects arising from the new

171. Crawford et al., supra note 169, at 893-94 (emphasis added).

172. Id. at 893 .

173. Id.

174. Id.

175. Fed. Trade Comm'n, Hearings on Competition and Consumer Protection in the 21st Century; FTC Hearing \#3: Multi-Sided Platforms, Labor Markets, and Potential Competition, Transcript, at 101 (Oct. 17, 2018) (statement of Robin Lee, Professor, Harvard University), https://www.ftc.gov /system/files/documents/public_events/1413712/ftc_hearings_session_3_transcript_day_3_10-17-18 _ 1.pdf [https://perma.cc/2QMU-Y5ZB] [hereinafter FTC Hearing \#3 Transcript] (emphasis added).

176. See Crawford et al., supra note 169 , at 894.

177. Id. ("Despite the richness of our empirical model, the effects that we document are only partial. Most importantly, our model and analysis do not allow vertical integration to influence investments made by RSNs and MVPDs (both those that integrate and their rivals). As emphasized in the literature on investment effects of vertical integration ... the direction of these effects on consumer and aggregate surplus are ambiguous a priori (and remain an important topic for future research)." (internal citations omitted)). 
corporate structure. Oftentimes, this is precisely why such transactions take place: not (solely) to avoid double marginalization and thus to offer outputs at lower prices, but to better coordinate R\&D at different levels of production in order to improve the return on (and increase the level of) investments (for example).

Second, although the results hold overall, it is clear that the presence of statutory program access rules affects the magnitude of the positive effects from integration. This highlights the importance of evaluating the broad institutional environment for assessing competitive effects and the difficulty of drafting broadly applicable guidelines. Every situation is different (not only because of differing legal environments, of course); the reasons and justifications for, and implementations of, vertical integration are complex and widely divergent. In short, the vast heterogeneity of circumstances, even within a single industry, ensures that predicting the welfare effects of a merger based on possibility theorems is a fool's errand.

\section{Suzuki}

Ayako Suzuki reviewed the vertical merger between Time Warner and Turner Broadcasting in order to analyze programming and distribution in the cable television market. ${ }^{178}$ The paper examined the merger's effects on foreclosure, per-channel prices, basic bundle product mix, and basic bundle penetration. ${ }^{179}$ The authors found foreclosure following the merger in Time Warner markets for those rival channels that were not integrated with any cable distributors. ${ }^{180}$ After the merger, two independent channels, the Disney Channel and the Fox News Channel, were foreclosed from Time Warner markets. ${ }^{181}$ They note that prior to the merger, two Turner channels (TBS and TCM) were foreclosed by Time Warner, but the foreclosure was ended after the merger: "Turner suffered from the low market shares of TBS and TCM in Time Warner markets, therefore it integrated itself with Time Warner in order to recover their market shares." 182

Suzuki concluded that per-channel prices decreased more in Time Warner markets than they would have in the absence of the merger. ${ }^{183}$ The paper suggests transaction cost efficiencies lowered the implicit cost to the

178. Ayako Suzuki, Market Foreclosure and Vertical Merger: A Case Study of the Vertical Merger Between Turner Broadcasting and Time Warner, 27 INT'L J. INDUS. ORG. 532, 532 (2009).

179. Id. at $532-33$.

180. Id. at 532 .

181. Id. at 541 .

182. Id. at 542 .

183. Id. 
distributor of the channels, causing input prices to shift downward, resulting in reduced cable price to consumers. ${ }^{184}$

Crawford et al. described the limitations of Suzuki's approach, noting that the studies cannot "separate efficiency from foreclosure incentives" and, more importantly, they cannot "provide estimates of overall welfare effects." 185 Crawford et al. also noted that "reduced carriage of rival nonintegrated channels could reflect either foreclosure effects or the impact of efficient increases in carriage of integrated channels when channels are substitutes." 186 What we do know is that, as an empirical matter, the clear weight of the evidence supports an overall presumption that such mergers are generally beneficial for consumers.

\section{The AT\&T/Time Warner Merger Enforcement Does Not Support the Adoption of Heightened Burdens on Vertical Mergers}

At the FTC Hearings, Salop pointed to the DOJ's case in its challenge of the AT\&T/Time Warner merger ${ }^{187}$ - then pending before the D.C. Circuit Court of Appeals, which has since upheld the district court's ruling in favor of the merging parties. ${ }^{188}$ The Court of Appeals even upheld District Court Judge Leon's overall approach to the case (despite his finding in favor of the merging parties), as a model for how vertical mergers should be assessed-claiming, in particular, that the approach was the same as that generally applied in the horizontal context. ${ }^{189}$

There is, in fact, no objection to the claim that evaluation of vertical mergers should follow a familiar rule of reason approach. But this does not mean that the application of presumptions or the extent and quality of sufficient evidence should be identical in every case. The rule of reason is perfectly consistent with the adoption of presumptions of legality where we know with confidence that the asserted theories of harm are unlikely

184. Id.

185. Crawford et al., supra note 169 , at 894 .

186. Id.

187. FTC Hearing \#5 Presentation Slides, supra note 10 , at 32.

188. United States v. AT\&T, Inc. (AT\&T-Time Warner), 916 F.3d 1029, 1047 (D.C. Cir. 2019) (affirming the district court ruling in United States v. AT\&T Inc., 310 F. Supp. 3d 161, 165 (D.D.C. 2018)).

189. AT\& T-Time Warner, 916 F.3d at 1032; see also FTC Hearing \#5 Transcript, supra note 21, at 31 ("That is the way Judge Leon wrote it in AT\&T-Time Warner; that is the way DOJ argued it in AT\&T-Time Warner. And I think an important point here is that the standard of proof builds in a greater concern with false negatives than with false positives. That is what the Clayton Act is all about, incipiency in the Clayton Act. So that is another reason why ... I think the vertical merger law should follow horizontal merger law, and I personally hope or expect that the D.C. Circuit is going to come out that way in AT\&T-Time Warner."). 
to pan out - this is just the inverse of the adoption of the per se standard. ${ }^{190}$

With respect to a desire that vertical mergers be evaluated under the standard rule of reason, there is no need to change the non-horizontal merger guidelines. ${ }^{191}$ In their current form, they do not apply a presumption that the identified potential harms from vertical mergers are any less problematic than those arising from horizontal mergers. Neither do they recommend adoption of a more lax or different procedure for vertical merger analysis. ${ }^{192}$ Notably, while the recent proposed draft Joint Vertical Merger Guidelines - which would update the 1984 Guidelinesstate explicitly that "[t]he principles and analytical frameworks used to assess horizontal mergers apply to vertical mergers,"193 the 1984 Guidelines also make repeated reference to the applicability of analytical standards from the Horizontal Merger Guidelines. ${ }^{194}$

Nevertheless, the notion that AT\&T/Time Warner shows the government pursuing a rule of reason case in the vertical merger contextexactly as it would in a horizontal context - is manifestly incorrect. In fact, any changes to the guidelines based on the DOJ's case and the court's process in AT\&T/Time Warner would actually move them away from where Salop (and others) want them to go.

To begin with, the government conceded efficiencies in the case from the outset, rather than relying on the defendants to produce evidence of countervailing efficiencies following the government's prima facie case as in a typical horizontal merger challenge. ${ }^{195}$ In effect, the government began with the presumption that the merger was procompetitive; and then offered what amounts to its own rebuttal that the inefficiencies outweighed the presumed efficiencies in making its initial case: effectively, that is, an

190. See generally Alan J. Meese, Price Theory, Competition, and the Rule of Reason, 2003 U. ILL. L. REV. 77 (2003).

191. NON-Horizontal Merger Guidelines, supra note $26, \S 4$.

192. Id. § 4.13 ("[T] $]$ he Department will evaluate mergers that raise either type of potential competition concern under a single structural analysis analogous to that applied to horizontal [sic] mergers."). The 1984 Guidelines do, as a prefatory matter, adopt a stance seemingly less concerned about vertical mergers. But the Guidelines themselves focus on the possible problems arising from vertical mergers and do not assume that any of the problems identified are inherently less serious or problematic than those arising from horizontal mergers. See id. $\S 4$.

193. DRAFt JoInt Vertical MERGER Guidelines, supra note $15, \S 1$.

194. See, e.g., NON-HORIZONTAL MERGER GUIDELINES, supra note $26, \S 4.13$ (“'[T]he Department will evaluate mergers that raise either type of potential competition concern under a single structural analysis analogous to that applied to horizontal mergers.").

195. See United States v. AT\&T Inc., 310 F. Supp. 3d 161, 194 (D.D.C. 2018) (“The Government concedes that the challenged merger, like most vertical mergers, will result in significant benefits to customers of the merged company."). 
inefficiencies argument. As the court put it:

To sum up, the Court accepts that vertical mergers "are not invariably innocuous," but instead can generate competitive harm "[i]n certain circumstances." The case at hand therefore turns on whether, notwithstanding the proposed merger's conceded procompetitive effects, the Government has met its burden of proof of establishing, through "case-specific evidence," that the merger of AT\&T and Time Warner, at this time and in this remarkably dynamic industry, is likely to substantially lessen competition in the manner it predicts. Unfortunately for the Government, . . . it did not meet its burden. ${ }^{196}$

The D.C. Circuit, in reviewing the district court decision, both recognized the district court's acceptance of presumed efficiencies and ruled specifically that this was not an error:

[T] he district court viewed the outcome of the litigation to "turn[] on whether, notwithstanding the proposed merger's conceded procompetitive effects, the Government has met its burden of establishing, through 'case-specific evidence,' that the merger of AT\&T and Time Warner, at this time and in this remarkably dynamic industry, is likely to substantially lessen competition in the manner it predicts."

Several amici urge this court to speak definitively on the proper legal standard for evaluating vertical mergers .... But there is no need to opine on the proper legal standards for evaluating vertical mergers because, on appeal, neither party challenges the legal standards the district court applied, and no error is apparent in the district court's choices .... 19

Neither Judge Leon, the DOJ, nor even the D.C. Circuit adopted Salop's preferred approach to vertical mergers. Indeed, the D.C. Circuit said:

[T] he district court found that the quantitative model as presented through Professor Shapiro's opinion testimony did not provide an adequate basis to conclude that the merger will lead to "any" raised costs for distributors or consumers, "much less consumer harms that outweigh the conceded \$350 million in annual cost savings to AT\&T's customers."

It is true that the district court misstated that the government had not proven that any price increases would "outweigh the conceded $\$ 350$ million in annual cost saving to AT\&T's customers."... The $\$ 352$

196. Id. (citations omitted).

197. AT\&T-Time Warner, 916 F.3d 1029, 1037 (D.C. Cir. 2019) (quoting $A T \& T, 310$ F. Supp. 3d at 194) (citations omitted). 
million ... was not cost savings to consumers but to AT\&T. But the district court did not weigh increased prices for consumers against cost savings for consumers, and instead found that the government had not shown at the first level that the merger was likely to lead to any price increases for consumers because of the failure to show that costs for rival MVPDs would increase as a result of Turner Broadcasting's increased leverage in affiliate negotiations after the merger. Counsel for the government and AT\&T agree the error regarding the consumer savings value alone would not require remand because the district court's opinion was not based on balancing any price increases against cost savings to consumers. Consequently, because the government failed to meet its burden of proof under its increased leverage theory at the first level, the error regarding cost savings was harmless error. ${ }^{198}$

The process the D.C. Circuit blessed was one in which the district court first assumed consumer welfare benefits and then looked to the government to make a case that corresponding inefficiencies undermined the assumed benefits. ${ }^{199}$ But the government failed to make the case that the inefficiencies were cognizable, and the presumption of benefit carried the day. ${ }^{200}$ This is not the standard rule of reason approach applied to horizontal mergers. Here the government conceded - and the court accepted-precisely what the defendants would have had to prove following a prima facie showing under a traditional balancing test.

This is not a minor decision. True, the court did not stop the trial and declare judgment for the parties because of the existence of procompetitive benefits; this was not a finding of per se legality. ${ }^{201}$ But, as the D.C. Circuit noted above, neither did the court actually weigh benefits against costs; rather, it assumed benefits and then, without really doing a balancing, determined that the government had not rebutted - and could not rebutthe presumption of benefit. Instead:

[T] he [DOJ's] loss should come as no surprise to observers when the DOJ concedes on the record that the transaction is expected to generate at least $\$ 350$ million in efficiencies annually while its own economic expert presents an estimated net harm that, as Judge Leon keenly observed, is statistically indistinguishable from zero. ${ }^{202}$

At the district court level, this is a thorough refutation of Salop's characterization of the DOJ's proposed conclusions of law (and Judge

198. Id. at 1046-47 (emphasis added) (quoting $A T \& T, 310$ F. Supp. 3d at 241) (citations omitted).

199. See id.

200. Id. at 1047 .

201. See AT\& T, 310 F. Supp. 3d at 194 n.20 ("The Court therefore declines defendants' invitation to adopt either a per se rule or a presumption that would apply to most vertical mergers.").

202. Joshua D. Wright \& Jan M. Rybnicek, United States v. AT\&T/Time Warner: A Triumph of Economic Analysis, 6 J. ANTITRUST ENFORCEMENT 459, 477 (2018). 
Leon's decision) as adopting an approach consistent with that taken in horizontal merger cases. That it was confirmed without objection from the parties and the D.C. Circuit is a rather complete rejection of this claim.

In his recent presentation at the FTC Hearings, Salop outlined what he thinks is a "proper" burden-shifting approach to vertical mergers - of the sort he would like to see embodied in new vertical merger guidelines. ${ }^{203}$ This approach would require of defendants:

Defendants may rebut a prima facie case only by showing that competitive harm is not "reasonably probable."

- Entry must be timely, likely, and sufficient to prevent competitive harm.

- Claimed efficiencies (which arguably cannot ever save a merger) must withstand "rigorous analysis."

- Defendants bear the burden of their efficiencies defense.

- Efficiencies must be reasonably verifiable, mergerspecific, and likely to benefit consumers in the affected markets, and must offset the harms of the merger.

- The Court cannot credit Defendants' purported efficiencies.

- A unilateral behavioral promise, such as an arbitration offer, cannot rebut a prima facie case. ${ }^{204}$

In point of fact, the district court in AT\&T-Time Warner rejected virtually all of these:

- It did not require timely entry because it adopted the position that the future was uncertain. ${ }^{205}$

- It did not demand that the defendants bear the burden of their efficiencies defense; rather, it simply credited the efficiencies conceded by the DOJ. ${ }^{206}$

- It did not weigh the benefits to consumers versus harms to

203. FTC Hearing \#5 Presentation Slides, supra note 10, at 32.

204. Id.

205. $A T \& T, 310$ F. Supp. 3d at 165.

206. See id. at 197-98. 
consumers, as the D.C. Circuit pointed out. ${ }^{207}$

- And, most overtly, it found that, indeed, the companies' "unilateral behavioral promise, such as an arbitration offer," rebutted the government's prima facie case. ${ }^{208}$

On this last point, the D.C. Circuit validated Judge Leon's reference to the consent order signed by the government in Comcast-NBCU, ${ }^{209}$ and put its own stamp of approval on the role of unilateral arbitration offers to alter the analysis in vertical merger cases:

[In Comcast-NBCU] the government had recognized, “"especially in vertical mergers, that conduct remedies,' such as the ones proposed [in Comcast-NBCU], 'can be a very useful tool to address the competitive problems while preserving competition and allowing efficiencies' that "may result from the transaction." Like there, the district court concluded the Turner arbitration agreements would have "real-world effect."

... Consequently, the government's challenges to the district court's treatment of its economic theories becomes largely irrelevant, at least during the seven-year period.... [A]nd Professor Shapiro acknowledged that taking the arbitration agreements into account would require "a completely different model."

... Neither Professor Shapiro's opinion testimony nor his quantitative model considered the effect of the post-litigation offer of arbitration agreements, something he acknowledged would require a new model. And the video programming and distribution industry had experienced "ever-increasing competitiveness" in recent years. Taken together, the government's clear-error contention therefore fails. ${ }^{210}$

The D.C. Circuit, like the lower court, found the unilateral promise of arbitration to be fatal to the government's case. ${ }^{211}$ Perhaps most importantly, Judge Leon continually found (and the D.C. Circuit fully supported) that changing market conditions rendered the government's contentions unreliable and arguably inapplicable. ${ }^{212}$ This is not a "neutral" presumption, nor is it the sort of anti-vertical-merger presumption

207. See id. at 241.

208. FTC Hearing \#5 Presentation Slides, supra note 10, at 32; AT\&T, 310 F. Supp. 3d at 217.

209. United States v. Comcast Corp. (Comcast-NBCU), 808 F. Supp. $2 d 145$ (D.C. Cir. 2011).

210. AT\&T-Time Warner, 916 F.3d 1029, 1041-46 (D.C. Cir. 2019) (quoting AT\&T, 310 F. Supp. $3 \mathrm{~d}$ at 161-217) (citations omitted).

211. Id. at 1041.

212. See AT\&T, 310 F. Supp. 3d at 242-49; AT\&T-Time Warner, 916 F.3d at 1046. 
proposed in Salop's slides. Instead, it is a non-merger-specific acknowledgment that puts a thumb on the scale in favor of private actors on the assumption that such conduct is presumptively beneficial or impossible to refute because information to the contrary is unreliable.

Indeed, contrary to the argument that Clayton Act Section 7's incipiency standard contemplates a lower standard of proof for the plaintiff's prima facie case, ${ }^{213}$ it actually seems clear (and correct) that error cost analysis would impose a higher burden on predictions of future outcomes precisely because they are uncertain. This is consistent with a general presumption in favor of such mergers, not against them. Of course, this does happen in horizontal merger cases, as well; there is, in fact, nothing vertical-specific about the skeptical treatment of incipiency claims. In this regard, it is not only appropriate for vertical merger guidelines to incorporate a lighter burden, but, arguably. the horizontal guidelines should do so, as well.

\section{THE ABSENCE OF ORGANIZATION THEORY AND DYNAMIC ANALYSIS FROM VERTICAL MERGER POLICY PROPOSALS}

The feared harms that are typically raised in objection to vertical mergers reveal the fundamental flaws in how antitrust practitioners and academics frequently view the markets and firms they analyze. In short, they are insufficiently sensitive to dynamic effects or too quick to assume that more atomized competition leads to more innovation.

The crucial question of how a market's structure affects innovation has occupied the world's brightest economists for almost a century, from Schumpeter who found that monopoly was optimal, ${ }^{214}$ through Arrow who concluded that competitive market structures were key, ${ }^{215}$ to the endogenous growth scholars who empirically derived an inverted-U relationship between market concentration and innovation. ${ }^{216}$ Despite these pioneering contributions to our understanding of competition and innovation, if the past century of innovation economics has taught us anything, it is that no market structure is strictly superior at generating innovation: "The literature addressing how market structure affects

213. See, e.g., FTC Hearing \#5 Presentation Slides, supra note 10, at 34 (“'Incipiency’ concern suggests a less demanding standard . . . This also suggests that (precise, if any) quantification should not be required.").

214. See J. A. SCHUMPETER, CAPITALISM, SOCIALISM AND DEMOCRACY 72 (1976).

215. See Kenneth Arrow, Economic Welfare and the Allocation of Resources for Invention, in THE RATE AND DIRECTION OF INVENTIVE ACTIVITY: ECONOMIC AND SOCIAL FACTORS 620 (Richard R. Nelson ed.,1962).

216. See, e.g., Philippe Aghion et al., Competition and Innovation: An Inverted-U Relationship, 120 Q.J. ECON. 701, 701-03 (2005). 
innovation (and vice versa) in the end reveals an ambiguous relationship in which factors unrelated to competition play an important role."217 Instead, in any given case, the right market structure likely depends on a plethora of sector- and firm-specific characteristics that range from the size and riskiness of innovation-related investments to the appropriability mechanisms used by firms, regulatory compliance costs, and the rate of technological change, among many others.

The economics that describe vertical integration as generally procompetitive are not, despite some claims to the contrary, designed to prefer monopoly power as a good in itself, but emerge as part of a recognition that the boundaries of firms are somewhat arbitrary from an outside perspective. The proper way to generate efficient outcomes is determined as much by transaction costs, corporate governance, asset specificity issues, and other intangible qualities of firms as it is by the static price considerations in narrow product markets.

Critics of vertical mergers do not often acknowledge the uncertainty surrounding the effects of changing firm and market structure on dynamic welfare. Advocates of a strong presumption against vertical mergers base their conclusions on analyses largely devoid of dynamic considerations. Indeed, as the authors of one study that acknowledges this limitation ${ }^{218}$ note, "[g]iven the current state of knowledge, we feel that such [strong] presumptions would be unwarranted at present." 219 While there is something of a dynamic element to the notion that vertical mergers affect horizontal competition by foreclosing entry or raising rivals' costs, the approach does not seem to entail a deep appreciation for the entrepreneurial, informational, and other organizational effects of vertical integration, which are fundamental to long-term consumer welfare in dynamic markets.

Thus, for example, criticisms of the AT\&T-Time Warner merger and the district court opinion in the case typically ignore the organizational justifications offered for the merger, including the changing market and the need for traditional business models to adapt in order to compete. ${ }^{220}$

217. Michael L. Katz \& Howard A. Shelanski, Mergers and Innovation, 74 ANTITRUST L.J. 1, 22 (2007).

218. Crawford et al., supra note 169 , at 894 ("[T] Most importantly, our model and analysis do not allow vertical integration to influence investments .... As emphasized in the literature on investment effects of vertical integration ... the direction of these effects on consumer and aggregate surplus are ambiguous a priori (and remain an important topic for future research).").

219. Gregory S. Crawford et al., AT\&T/Time Warner and Antitrust Policy Toward Vertical Mergers, CPI ANTITRUST CHRON., July 2019, at 1, 5.

220. See, e.g., Geoffrey A. Manne, There's No Antitrust Case Against AT\&T, WALl StREET J. 
[But] even if [vertical restraints] appear to limit distribution, they spur the creation of new content and new modes of distribution. Americans today are already cutting cords and unbundling their viewing. Multiple distribution models, each with a unique collection of content, can ably compete.

AT\&T signed a deal with Taylor Swift to create and distribute "behind the scenes" videos. Dish Network's Sling TV is offering "skinny bundles" of select channels. CBS has launched its own standalone streaming service. Amazon is bundling original programming into a Prime subscription. Such innovations would not exist without the ability to offer exclusive content or unique arrangements to attract customers. A merged AT\&T-Time Warner, with tighter integration of content and distribution, would generate further experimentation and have an enhanced ability to compete in this environment. ${ }^{221}$

Instead, "the static analysis of the bargaining problem [undergirding the DOJ's case] ignores complexities associated with the dynamic nature of the market, complexities that show the merger is efficient and unlikely to adversely affect the short run competitive process."222

As noted previously, much of the mainstream economics undergirding merger analysis is dismissive of organization theory and thus also dismissive of many of the "non-standard and unfamiliar contractual practices and organizational structures.... [W] hereas transaction cost economics holds that organization both matters and is susceptible to analysis." 223 This systematically ensures that orthodox analyses fail to account for the organizational structures, processes, and choices conducive to generating dynamic welfare. As Professors Jorde \& Teece note:

For innovations to be commercialized, the economic system must somehow assemble all the relevant complementary assets and create a dynamically-efficient interactive system of learning and information exchange. The necessary complementary assets can conceivably be assembled by either administrative or market processes, as when the innovator simply licenses the technology to firms that already own or are willing to create the relevant assets. These organizational choices have received scant attention in the context of innovation. Indeed, the serial

(Nov. 21，2017，6:22 PM), https://www.wsj.com/articles/theres-no-antitrust-case-against-at-t -1511306560 [https://perma.cc/JZN6-HKP5].

221. Id. (emphasis added).

222. Malcolm B. Coate, Can Vertical Merger Analysis Be Salvaged After the AT\&T/Time-Warner Merger Decision?, CPI ANTITRUST ChrON., July 2019, at 23, 25. This point was also recognized by the district court. See United States v. AT\&T, Inc., 310 F. Supp. 3d 161, 243 (D.D.C. 2018) ("The entire premise of the proposed merger — allowing AT\&T to go mobile with video content — provides yet another reason to reject the Government's unilateral merger theory.").

223. Williamson, supra note 50, at 938. 
model relies on an implicit belief that arm's-length contracts between unaffiliated firms in the vertical chain from research to customer will suffice to commercialize technology. In particular, there has been little consideration of how complex contractual arrangements among firms can assist commercialization - that is, translating $R \& D$ capability into profitable new products and processes. The one partial exception is a tiny literature on joint R\&D activity, but this literature addresses the organization of $\mathrm{R} \& \mathrm{D}$ and not the organization of innovation.

But in reality, the market for know-how is riddled with imperfections. Simple unilateral contracts where technology is sold for cash are unlikely to be efficient. Complex bilateral and multilateral contracts, internal organization, or various hybrid structures are often required to shore up obvious market failures and create procompetitive efficiencies. ${ }^{224}$

Whatever the claimed price effects of increased concentration, if they are not accompanied by an assessment of industry-wide increases in innovation and of quality improvements that may have accompanied the price increases, it is impossible to conclude that they are an indication of anticompetitive conduct - or even that they are harmful at all. Rather, price increases accompanied by concomitant or even greater quality increases, as well as increased market innovation (that may result in future quality improvements), are consistent with consumer-welfare-enhancing behavior, and these benefits must also be evaluated before any conclusions can legitimately be drawn.

As Allen Gibby and Geoffrey Manne have noted in the ag/biotech context (a decidedly and increasingly oligopolistic industry):

While the agriculture industry has a long history of successful crosslicensing arrangements between agricultural input providers, licensing talks can, of course, break down (and do so for any number of reasons), potentially thwarting a nascent product before research has even begun-or, possibly worse, well into its development. The cost of such a breakdown is not merely the loss of the intended product; it is also the opportunity cost of the foregone products Company A could have been developing, as well as the costs of negotiation.

To mitigate the risks inherent in these arm's-length negotiations, as well as to avoid other impediments to efficient R\&D (like delays resulting from waiting years for Company B to fully develop and make available a chemical before it engages in negotiations with Company A), firms may merge to fully integrate their knowledge and capabilities. Where these and other impediments may arise, integration may well be the lowest-cost way of organizing assets in order to maximize their 
value. This is especially true for R\&D-intensive industries where intellectual property and innovation are fundamental to obtaining or maintaining a competitive advantage. Absent integration, neither party would have an incentive to fully disclose the nature of its intellectual property and innovation pipeline. Integration can thus increase both the likelihood and the efficiency of information sharing, enabling managers to effectively evaluate and reorganize assets in ways that maximize return on investment. ${ }^{225}$

By contrast, a necessary corollary of enforcement policy aimed at increasing the alleged competitive effects of indirect competition by increasing enforcement efforts aimed at vertical integration ${ }^{226}$ is the imposition of an effective duty to deal upon vertically related firmsprecisely the opposite of the strategic and nuanced forms of organization and coordination that innovative markets require. Put differently, an approach that rests on the loss of indirect competition to justify challenging a vertical merger must also rest on the existence of that indirect competition in the but-for world. Because such competition (i.e., the supply of inputs (access to customers) to all competitors in the downstream (upstream) market) cannot be certain to arise, the theory implicitly presupposes the imposition of a mandatory duty to deal when it does not. If not, the claimed competitive forces that would be lost from a merger relative to the but-for world are not, in fact, necessarily lost.

The common bias in antitrust is to think about everything in terms of product markets, which may (or may not) be appropriate in the context of horizontal mergers, but is certainly incomplete when thinking about vertical mergers. Vertical mergers are at least as often about the organization of production, especially in high tech markets, where these firms are considering strategies to survive future Schumpeterian disruption, as well as trying to get $\mathrm{R} \& \mathrm{D}$ right for what consumers want in five years.

Focusing solely on the product market in a vertical merger makes an enforcer miss the forest for the trees. Although competition for the market (as opposed to competition in the market) is frequently a crucial driver of innovation, it is only tangentially addressed even by current antitrust regimes. Instead, these laws tend to focus more heavily on competition

225. Geoffrey A. Manne \& Allen Gibby, A Brief Assessment of the Procompetitive Effects of Organizational Restructuring in the Ag-Biotech Industry 7 (Int'1 Ctr. For Law \& Econ. Antitrust \& Consumer Prot. Research Program, White Paper No. 2017-2, May 9, 2017), http://laweconcenter.org /images/articles/icle-ag_mergers_short_paper_final.pdf [https://perma.cc/N4BH-BGRL].

226. FTC Hearing \#5 Presentation Slides, supra note 10, at 15 ("[T] he upstream merging firm that supplies a downstream firm is inherently an 'indirect competitor' of the future downstream merging firm. That indirect competition is eliminated by merger. This unilateral effect is exactly parallel to the unilateral effect from a horizontal merger."). 
within well-defined markets - that is, on competition in the market. ${ }^{227}$ In that regard, the indicia of competition upon which current antitrust regimes tend to focus may, when considered within the context of innovation, point in the wrong direction. Indeed, whereas competition for the market is a key driver of innovation, it does not follow that ever-more competition in each and every market is necessary, or even desirable, to achieve the optimal rate of innovation in an economy. ${ }^{228}$

Consideration of dynamic markets entails a very different approach:

Thus, indicia for defining high technology markets must focus on competitive conditions and competitive activity. There must be an investigation of behavior and actions and generally over a longer time horizon than the standard 1-2 years. Standard indicia, and particularly the hypothetical monopolist test, using the SSNIP (at or near a 5-10\% level) will surely define markets too narrowly. If it is difficult to determine an appropriate SSNIP (whether the "P" is interpreted as "price" or "performance") so that markets can be confidently defined, then one can endeavor to assess whether monopoly power exists by assessing:

- innovative activity (e.g., research and development expenditures and trends, product innovations and introductions, and performance enhancements);

- competitive activity (e.g., shifts in share, the impact of potential entry, shifts in customer purchases); and

- $\quad$ pricing responses and flexibility. ${ }^{229}$

Of perhaps greatest significance, the impact of each organizational form on knowledge transfers creates a particularly strong division between integration and contract. As Enghin Atalay, Ali Hortaçsu, and Chad Syverson point out:

That vertical integration is often about transfers of intangible inputs rather than physical ones may seem unusual at first glance. However, as observed by Arrow (1975) and Teece (1982), it is precisely in the transfer of nonphysical knowledge inputs that the market, with its

227. See William M. Landes \& Richard A. Posner, Market Power in Antitrust Cases, 94 HARV. L. REV. 937, 960 (1981).

228. Harold Demsetz, The Intensity and Dimensionality of Competition, in THE ECONOMICS OF THE BUSINESS FIRM: SEVEN CRITICAL COMMENTARIES 137, 140-41 (1995) ("Once perfect knowledge of technology and price is abandoned, [competitive intensity] may increase, decrease, or remain unchanged as the number of firms in the market is increased .... [I]t is presumptuous to conclude ... that markets populated by fewer firms perform less well or offer competition that is less intense.").

229. Christopher Pleatsikas \& David J. Teece, The Analysis of Market Definition and Market Power in the Context of Rapid Innovation, 19 INT'L J. INDUS. ORG. 665, 689-90 (2001). 
associated contractual framework, is most likely to fail to be a viable substitute for the firm. Moreover, many theories of the firm, including the four "elemental" theories as identified by Gibbons (2005), do not explicitly invoke physical input transfers in their explanations for vertical integration. ${ }^{230}$

Particularly in the high-tech setting, the role of intangible assets in encouraging merger over contracting (and, in turn, the dynamic consequences of mergers versus contracts) is both extremely important and woefully absent from antitrust law and theory. As Daniel Sokol has written:

For the past thirty years, antitrust literature has largely ignored the significant literature within strategy related to vertical integration in the technology setting. Overall, this literature shows the important efficiency-enhancing effects of vertical mergers. These mergers are largely complementary, combining the strengths of the acquiring firm in process innovation with the product innovation of the target firms. This literature helps to push for a presumption for vertical merger law and policy to generally tolerate vertical mergers.

... Many large firms acquire smaller firms in vertical mergers with the belief that the acquisition will allow the acquirer to create efficiencies that are not possible merely by licensing, strategic alliance, or joint venture.

Large firms need acquisitions to help with innovation. Innovation is critical for firms because greater innovation leads to improved financial returns. ...

... A number of reasons explain this strategy of acquisition vis-à-vis internal growth. This includes lower entry barriers via acquisition, acquisition of intellectual property and research and development $(R \& D)$ that can be used strategically, knowledge, economies of scale and scope, and the ability to exert greater control rights through vertical integration via merger rather than via contract. ${ }^{231}$

Finally, although difficult to verbalize and often unappreciated by managers themselves, successful, innovative businesses are characterized by "dynamic capabilities." Among other things, these derive from close managerial control over a range of inputs and processes internal to a firm:

[D]ynamic capabilities are about doing the right things, at the right time, based on unique managerial orchestration processes, a strong and

230. Enghin Atalay et al., Vertical Integration and Input Flows, 104 AM. ECON. REV. 1120, 1121 (2014) (emphasis added).

231. Sokol, Vertical Mergers, supra note 12, at 1371-73 (emphasis added) (footnotes omitted). 
change-oriented organizational culture, and a prescient assessment of the business environment and technological opportunities. . . . $\cdots$

Dynamic capabilities reside, in part, with individual managers and the top management team. At certain key junctures, the ability of a CEO and the top management team to recognize a key development or trend, then delineate a response and guide the firm in its co-creation activities, may be the most important element of the firm's dynamic capabilities. But the organization's values, culture, and its collective ability to quickly implement a new business model or other changes are also integral to the strength or weakness of the firm's dynamic capabilities.

$\cdots$

Because of their deep, enterprise-specific roots, signature processes are not so easily imitated by other firms that did not and cannot share this history and that may have a different, incompatible corporate culture as well. Moreover, the replicability of a process or business model is often confounded, particularly externally, by what Lippman and Rumelt (1982) call "uncertain imitability."

Jorde and Teece noted this too, nearly thirty years ago, as a reality of multiple coordinate models of relevant markets: the product market, the "know how" market and the market for complementary goods. ${ }^{233}$

Indeed, antitrust analysis of complex business arrangements which ignores the primacy of innovation will frequently fail. New intellectual paradigms are necessary to understand how competition takes place in many industries today. These paradigms must move beyond a narrow focus on market structure as the determinant of competitive considerations. Frames of analysis must be broadened far beyond the market structure-conduct-performance paradigm to include appropriability regimes, capital markets, the market for know-how, and the market for what we will call complementary assets. Traditional market structure analysis will yield reliable results only in limited circumstances that have become increasingly rare in today's global economy. ${ }^{234}$

The market for "know how" incorporates, among other things, all of the intangible assets of a firm that facilitate production, which can to varying degrees be considered appropriable as intellectual property. ${ }^{235}$

232. David J. Teece, Intangible Assets and a Theory of Heterogeneous Firm, in INTANGIBLES, MARKET FAILURE AND INNOVATION PERFORMANCE 217, 228 (Bounfour \& Miyagawa eds., 2015).

233. Jorde \& Teece, supra note 51 , at 580.

234. Id. at $579-80$.

235. See id. at 591. 
When intellectual property protection for a given set of valuable pieces of "know how" is strong - easily defendable, unique patents, for examplefirms can rely on property rights to efficiently contract with vertical buyers and sellers. ${ }^{236}$ But in cases where the valuable "know how" is less easily defended as IP, trade secrets, or some other legally recognized property right - e.g. business process innovation, managerial experience, and the like - the ability to partially vertically integrate through contract becomes more difficult, if not impossible. ${ }^{237}$

Thus, static analysis, while useful, and while it certainly has its place, quickly runs into problems when dealing with dynamic firms that create ecosystems of products and services that compete with each other. As Professor Mark Jamison notes:

Competition through innovation and the vulnerability of some tech business models make it futile to base antitrust on market definition and price sensitivities. The practices used to define markets and examine upward pressure on prices rely on stable products and demand and historical data that are directly relevant to making decisions about the future. This reliance is misplaced, as rapid change makes the present and past poor representations of the future. Hauge and Jamison call this "decay," by which they mean that as time passes, facts about the past decline in relevance for regulatory action. ${ }^{23}$

Jamison is pointing in the right direction in this observation. He goes on to advocate for antitrust analysis to consider what he calls "resource fluidity" 239 and proposes an interesting framework where enforcers need to look at the full life-cycle of a firm and product, from $\mathrm{VC}$ funding through production iterations, and ultimate profit-taking to determine if the firms, considered dynamically, were behaving in procompetitive ways. $^{240}$ It is a valuable and important insight, but even this approach needs to be broadened.

Not only should we look at the dynamics of a particular production lifecycle, as Jamison suggests, but we should consider the dynamic tensions that exist in the firm as a whole, from supply chain and production through management style, culture, and the firm-specific resources and talents that impact the competitive decisions in question. There is a large economics and organization theory literature discussing how

236. See id. at 594.

237. See id.

238. Mark Jamison, Applying Antitrust in Digital Markets: Foundations and Approaches 11 (Am. Enter. Inst. Working Paper 2019-18, Nov. 2019), https://www.aei.org/wp-content/uploads/2019/11 /Jamison-Digital-Markets-WP.pdf (citations omitted).

239. Id. at 17 .

240. Id. at $15-20$. 
organizations are structured with respect to these sorts of intangible assets. $^{241}$ And the upshot of all of them is that, while we start - not end, as Professor Salop would have $\mathrm{it}^{242}$-with the Coasian insight that firm boundaries are necessarily a function of production processes and not a hard limit, we quickly come to realize that it is emphatically not the case that integration-via-contract and integration-via-merger are always or even often viable substitutes.

\section{CONCLUSION}

The contemporary complaints about vertical integration are old wine in new bottles: much of the ground in recent complaints about vertical mergers has been tread over the course of the twentieth century. Moreover, empirical research consistently demonstrates that vertical mergers are either procompetitive or, at worst, competitively neutral. The possibility theorems offered by opponents of vertical mergers to justify invigorated enforcement against them rely on fragile claims that ignore the meaningful distinction between contracts and mergers, and between harms that are likely to arise via horizontal integration and those by vertical integration.

Perhaps more problematic than merely getting the analysis wrong, this crusade against vertical mergers leads us to examine outdated and unproductive questions. The narrow conception offered by those advocating for a revolution in antitrust law that would create presumptions against vertical mergers threatens to undermine dynamic competition and innovation. Organizational forms aimed at solving strategic management problems and aimed at facilitating dynamic competition are overlooked by this approach. Yet competition among modern firms-even (or especially) oligopolistic firms in fast-moving, high-tech industries-is takes place primarily on this dimension. These firms operate what amounts to product and service ecosystems that compete with other firms' ecosystems along numerous dimensions and across time. Looking for simplistic (and analytically incorrect) stories about structural foreclosure

241. See, e.g., David J. Teece, Profiting from Technological Innovation: Implications for Integration, Collaboration, Licensing and Public Policy, 15 RES. POL'Y 285 (1986); Sidney G. Winter, The Logic of Appropriability: From Schumpeter to Arrow to Teece, 35 RES. POL'Y 1100 (2006); ANTITRUST, INNOVATION, AND COMPETITIVENESS (Thomas M. Jorde \& David J. Teece eds., 1992); Oliver E. Williamson, The Mechanisms of GovernanCE (1996); Henry W. Chesbrough \& David J. Teece, When Is Virtual Virtuous?: Organizing for Innovation, 1996 HARV. BUS. REV. 65 (1996); Richard Schmalensee, Standard-Setting, Innovation Specialists, and Competition Policy, 57 J. INDUS. ECON. 526 (2009); Richard C. Levin et al., Appropriating the Returns from Industrial Research and Development, 1987 BROOKINGS PAPERS ON ECON. ACTIVITY 783 (1987).

242. Salop, AT\&T, supra note 40, at 468-69. 
in static markets leads us to miss the proper evaluation of the dynamic competitive effects of vertical arrangements across the broader, more complex, evolving markets in which these firms actually operate.

In this frame, there may very well exist increases in innovation (including especially business model innovation) and quality improvements along some dimensions, alongside superficial price increases or localized constraints on innovation along other dimensions. To determine if a particular merger is truly anticompetitive requires a careful balancing of all of these considerations against each other. Although it may take less cognitive work to look for simple stories in a relatively static price analysis in narrow markets, this would ultimately do consumers a disservice. 